\title{
Latitudinal variation in the multiphase chemical processing of inorganic halogens and related species over the eastern North and South Atlantic Oceans
}

\author{
W. C. Keene ${ }^{1}$, M. S. Long ${ }^{1}$, A. A. P. Pszenny ${ }^{2,3,{ }^{*} \text {, R. Sander }}{ }^{4}$, J. R. Maben ${ }^{1}$, A. J. Wall ${ }^{3, * *}$, T. L. O'Halloran ${ }^{1, * * *}$, \\ A. Kerkweg ${ }^{4, * * * *}$, E. V. Fischer ${ }^{3, * * * * *}$, and O. Schrems ${ }^{5}$ \\ ${ }^{1}$ Department of Environmental Sciences, University of Virginia, Charlottesville, VA 22904, USA \\ ${ }^{2}$ Institute for the Study of Earth, Oceans, and Space, University of New Hampshire, Durham, NH, 03824, USA \\ ${ }^{3}$ Mount Washington Observatory, North Conway, NH, 03860, USA \\ ${ }^{4}$ Air Chemistry Department, Max-Planck Institute of Chemistry, 55020 Mainz, Germany \\ ${ }^{5}$ Alfred Wegener Institute for Polar and Marine Research, 27515 Bremerhaven, Germany \\ *now at: Atmospheric Chemistry Program, National Science Foundation, Arlington, VA, 22230, USA \\ *** now at: Department of Geosciences, Pennsylvania State University, University Park, PA, 16802, USA \\ **** now at: Department of Forest Ecosystems and Society, Oregon State University, Corvallis, OR, 97330, USA \\ ***** now at: Institute for Atmospheric Physics, University of Mainz, 55020 Mainz, Germany \\ ***** now at: Department of Atmospheric Sciences, University of Washington, Seattle, WA 98195, USA
}

Received: 30 March 2009 - Published in Atmos. Chem. Phys. Discuss.: 14 May 2009

Revised: 4 September 2009 - Accepted: 9 September 2009 - Published: 2 October 2009

\begin{abstract}
Volatile inorganic and size-resolved particulate $\mathrm{Cl}$ - and $\mathrm{Br}$-species were measured in near-surface air over a broad range of conditions within four distinct regimes (European - EURO, North African - N-AFR, the Intertropical Convergence Zone - ITCZ, and South Atlantic - S-ATL) along a latitudinal gradient from $51^{\circ} \mathrm{N}$ to $18^{\circ} \mathrm{S}$ through the eastern Atlantic Ocean. Median dry-deposition fluxes of sea salt, oxidized $\mathrm{N}$, and oxidized non-sea-salt $\mathrm{S}$ varied by factors of 25,17 , and 9 , respectively, among the regimes. Sea-salt production was the primary source for inorganic $\mathrm{Cl}$ and $\mathrm{Br}$. Acidification and dechlorination of sea salt primarily by $\mathrm{HNO}_{3}$ sustained $\mathrm{HCl}$ mixing ratios ranging from medians of 82 (ITCZ) to 682 (EURO) pmol mol ${ }^{-1}$. Median aerosol $\mathrm{pHs}$ inferred from $\mathrm{HCl}$ phase partitioning with super $-\mu \mathrm{m}$ size fractions ranged from $\sim 3.0$ for EURO to $\sim 4.5$ for ITCZ. Because $\mathrm{SO}_{2}$ solubility over this $\mathrm{pH}$ range was low, S(IV) oxidation by hypohalous acids was unimportant under most conditions. Simulations with a detailed multiphase box model indicated that $\mathrm{BrCl}$ photolysis and $\mathrm{ClO}+\mathrm{NO}$ were the major sources for atomic $\mathrm{Cl}$ in all regimes. Simulated midday concentrations of $\mathrm{Cl}$ atoms
\end{abstract}

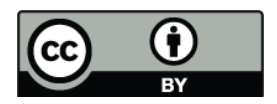

Correspondence to: W. C. Keene (wck@virginia.edu) ranged from $2.1 \times 10^{4}$ to $7.8 \times 10^{4} \mathrm{~cm}^{-3}$ in the ITCZ and NAFR regimes, respectively. Measured particulate $\mathrm{Br}^{-}$(median enrichment factor $=0.25$ ) was greater and volatile inorganic $\mathrm{Br}$ less than simulated values, suggesting that the halogen activation mechanism in the model overestimated $\mathrm{Br}$-radical production and processing. Reaction with atomic $\mathrm{Br}$ was an important sink for modeled $\mathrm{O}_{3}$ (5\% in EURO to $46 \%$ in N-AFR). Formation of halogen nitrates accelerated the oxidation of $\mathrm{NO}_{\mathrm{x}}\left(\mathrm{NO}+\mathrm{NO}_{2}\right)$ primarily via hydrolysis reactions involving $\mathrm{S}$ aerosol. Relative to simulations with no halogens, lower $\mathrm{NO}_{\mathrm{x}}$ coupled with direct reactions involving halogens yielded lower steady state mixing ratios of $\mathrm{OH}$ (20\% to $54 \%$ ) and $\mathrm{O}_{3}(22 \%$ to $62 \%)$ and lower midday ratios of $\mathrm{OH}: \mathrm{HO}_{2}(3 \%$ to $32 \%)$ in all regimes.

\section{Introduction}

Chemical reactions involving inorganic halogens significantly influence the composition of the Earth's atmosphere. The importance of these reactions was first recognized in connection with stratospheric ozone loss, especially within the polar vortices during spring (e.g., Wennberg et al., 1994). In the troposphere, the multiphase processing of reactive

Published by Copernicus Publications on behalf of the European Geosciences Union. 
halogens significantly modifies conventional $\mathrm{HO}_{\mathrm{x}} / \mathrm{NO}_{\mathrm{x}}$ photochemistry over Arctic and Antarctic sea ice (Foster et al., 2001; Simpson et al., 2007), salt flats (Matveev et al., 2001), coastal cities (Finley and Saltzman, 2006; Osthoff et al, 2008), polluted coastal regions (Pszenny et al., 2007; Pechtl and von Glasow, 2007), and coastal-marine macroalgal beds (Alicke et al., 1999). Modeling studies and observations suggest that transformations involving reactive halogens in the marine boundary layer (MBL) over the open ocean are potentially of much greater global significance in terms of the processing and lifetimes of climatically important gases (e.g., von Glasow et al., 2002a, b; Read et al., 2008; Lawler et al., 2009).

The primary source of reactive inorganic $\mathrm{Cl}$ and $\mathrm{Br}$ in marine air is the production of sea-salt aerosols by waves breaking at the sea surface (Keene et al., 1999; Sander et al., 2003; respectively) whereas the major sources of reactive I include emission of biogenic iodocarbons from the ocean surface and, in coastal regions, from exposed macroalgae at low tide (Carpenter, 2003); direct emissions of $I_{2}$ from macroalgae (Saiz-Lopez and Plane, 2004) and from the surface microlayer of the ocean (Martino et al., 2009) may also be important. The multiphase photochemical processing of marinederived halogens influences oxidation capacity through an interrelated set of reactions including catalytic $\mathrm{O}_{3}$ destruction (Dickerson et al., 1999; Nagao et al., 1999; Galbally et al., 2000; Read et al., 2008); net $\mathrm{O}_{3}$ production in polluted regions (Tanaka et al., 2003; Osthoff et al., 2008); oxidation of $\mathrm{CH}_{4}$ (Platt et al., 2004), non-methane hydrocarbons (NMHCs; Wingenter et al., 1996; Pszenny et al., 2007), and $\left(\mathrm{CH}_{3}\right)_{2} \mathrm{~S}$ (Toumi, 1994; Keene et al., 1996; Saiz-Lopez et al., 2004) in the gas phase; oxidation of S(IV) in aerosol solutions (Vogt et al., 1996); and modification of $\mathrm{HO}_{\mathrm{x}}$ (Stutz et al., 1999; Bloss et al., 2005) and $\mathrm{NO}_{\mathrm{x}}$ cycles (Sander et al., 1999; Pszenny et al., 2004). The associated production of soluble reaction products contributes to aerosol growth. Reactions involving iodine oxides have also been linked to significant nucleation of new particles in some coastal regions (e.g., O'Dowd et al., 2002) but not in others (Russell et al., 2007). The potential importance of these pathways over the open ocean is unknown. Finally, the phase partitioning of $\mathrm{HCl}$ regulates the $\mathrm{pH}$ of marine aerosol solutions and important associated $\mathrm{pH}$-dependent pathways including halogen activation and S(IV) oxidation (Keene et al., 1998; 2004). Despite the potential importance of reactive halogen chemistry, comprehensive multiphase observations over a broad range of tropospheric conditions, and particularly over the open ocean, are scarce thereby constraining our ability to reliably predict associated influences on $\mathrm{O}_{3}$ cycling, oxidation processes, aerosol evolution, and radiative transfer regionally and globally. This limitation motivated the investigation reported herein.

\section{Methods}

\subsection{Cruise track and shipboard sampling}

During an October and November 2003 cruise of the German research ship Polarstern from Bremerhaven, Germany to Cape Town, South Africa (designated cruise number ANT $\mathrm{XXI} / 1$ ), a suite of reactive trace gases, size-resolved and bulk aerosol composition, and related meteorological conditions was measured in near-surface air over the eastern Atlantic Ocean along a latitudinal transect from $51.4^{\circ} \mathrm{N}$ to $17.8^{\circ} \mathrm{S}$ (Fig. 1). Air was sampled from the top of a walkup aluminum scaffold mounted above the navigation bridge approximately $5 \mathrm{~m}$ port of the ship's center line (schematics of the ship are available on the web at http://www.awi. de/en/infrastructure/ships/polarstern/; also see supplementary material, Fig. S1, http://www.atmos-chem-phys.net/9/ 7361/2009/acp-9-7361-2009-supplement.pdf). Inlets were positioned approximately $23 \mathrm{~m}$ above the water line. All sampling was suspended during two large, multi-day storm events (from $43.4^{\circ} \mathrm{N}$ to $32.8^{\circ} \mathrm{N}$ and from $17.8^{\circ} \mathrm{S}$ to the end of the cruise) during which strong winds, bow spray, and/or heavy rain precluded contamination-free sampling. Aerosol sampling was also suspended intermittently during periods of scattered precipitation.

\subsection{Measurements}

\subsubsection{Reactive trace gases}

Water-soluble, volatile inorganic chlorine and oxidized nitrogen (dominated by and hereafter referred to as $\mathrm{HCl}$ and $\mathrm{HNO}_{3}$, respectively), $\mathrm{NH}_{3}, \mathrm{HCOOH}$, and $\mathrm{CH}_{3} \mathrm{COOH}$ were sampled over 2-h intervals at nominal flow rates of $20 \mathrm{~L} \mathrm{~min}^{-1}$ with a single set of tandem mist chambers, each of which contained $20 \mathrm{ml}$ deionized water (Keene et al., 2007a). All air volumes reported herein are normalized to standard temperature and pressure $\left(0^{\circ} \mathrm{C}, 1 \mathrm{~atm}\right)$. To minimize artifact phase changes caused by mixing chemically distinct aerosol size fractions on bulk prefilters, air was sampled through a size-fractionating inlet that inertially removed super- $\mu \mathrm{m}$ aerosols from the sample stream. Sub- $\mu \mathrm{m}$ aerosol was removed downstream by an in-line $47-\mathrm{mm}$ Teflon filter (Zefluor $2-\mu \mathrm{m}$ pore diameter). In-line filters were changed daily. Samples were analyzed on site by ion chromatography (IC) usually within a few hours after recovery. Data for these samples as well as those for gas and aerosol samples described below were corrected based on dynamic handling blanks that were loaded, briefly (few seconds) exposed to ambient air flow, recovered, processed, and analyzed using procedures identical to those for samples. Collection efficiencies for all species were greater than $95 \%$ and, consequently, corrections for inefficient sampling were not necessary. Relative precisions based on paired measurements varied as functions of concentration and typically 


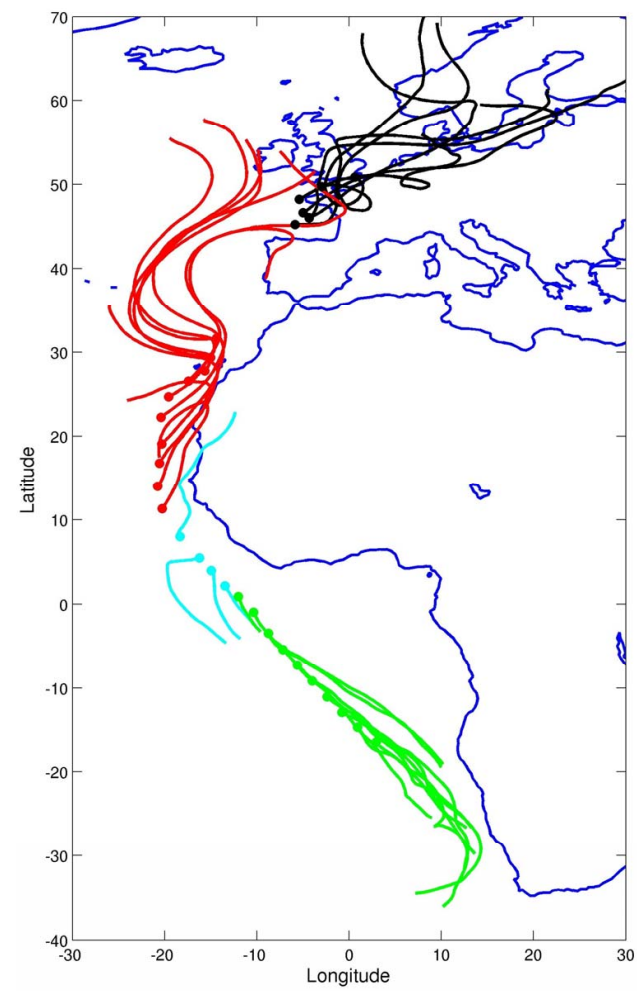

Fig. 1. Five-day HYSPLIT back trajectories initiated at 500-m elevation along the cruise track. Start times correspond to the midpoint of each aerosol and filter-pack sampling interval. Trajectories for the EURO regime are plotted in black, N-AFR in red, ITCZ in light blue, and S-ATL in green.

averaged $\pm 10 \%$ to $\pm 25 \%$. Average detection limits (DLs; estimated following Keene et al. (1989) for both mist chamber and aerosol samples) for $\mathrm{HCl}, \mathrm{HNO}_{3}, \mathrm{NH}_{3}, \mathrm{HCOOH}$, and $\mathrm{CH}_{3} \mathrm{COOH}$ were $23,2,19,13$, and $19 \mathrm{pmol} \mathrm{mol}^{-1}$, respectively.

Inorganic $\mathrm{Cl}$ gases were sampled in parallel through an identical inlet with two sets of similar tandem mist chamber samplers (Keene et al., 1993; Maben et al., 1995; Pszenny et al., 2004; Keene et al., 2007a). One sampler was configured with an upstream chamber containing acidic solution [37.5 $\mathrm{mM} \mathrm{H}_{2} \mathrm{SO}_{4}$ and $0.042 \mathrm{mM}\left(\mathrm{NH}_{4}\right)_{2} \mathrm{SO}_{4}$ ], which removed $\mathrm{HCl}$ quantitatively but efficiently passed other forms of volatile $\mathrm{Cl}$, and a downstream chamber containing alkaline solution [ $30.0 \mathrm{mM} \mathrm{NaHCO} 3$ and $0.408 \mathrm{mM} \mathrm{NaHSO}_{3}$ ], which sampled $\mathrm{Cl}^{*}$ (including $\mathrm{Cl}_{2}, \mathrm{HOCl}$, and probably contributions from $\mathrm{ClNO}_{3}, \mathrm{ClNO}_{2}, \mathrm{BrCl}, \mathrm{ClO}$, and $\mathrm{Cl}$ ). The other sampler was configured with tandem chambers, both of which contained alkaline solution to sample total volatile inorganic $\mathrm{Cl}\left(\mathrm{Cl}_{t}\right)$. Available evidence (Keene et al., 1993; Maben et al., 1995) indicates that this sampling technique reliably discriminates volatile inorganic $\mathrm{Cl}$ from $\mathrm{Cl}$ associated with both particles and organic gases and that it quantitatively differentiates between $\mathrm{HCl}$ and other forms of volatile inorganic $\mathrm{Cl}$. However, the speciation of $\mathrm{Cl}^{*}$ cannot be deter- mined unequivocally. Mist solutions were analyzed on site by IC. The average relative precision for both $\mathrm{Cl}^{*}$ and $\mathrm{Cl}_{t}$ was approximately $\pm 15 \%$ or $\pm 12 \mathrm{pmol} \mathrm{Cl} \mathrm{mol}^{-1}$, whichever was the greater absolute value, and the corresponding average DL for both analytes was $24 \mathrm{pmol} \mathrm{Cl} \mathrm{mol}^{-1}$.

Total volatile inorganic $\mathrm{Br}\left(\mathrm{Br}_{t}\right)$ and $\mathrm{SO}_{2}$ were sampled at a nominal rate of $80 \mathrm{~L} \mathrm{~min}^{-1}$ over discrete daytime and nighttime periods using a filterpack technique (Pszenny et al., 2004). An open-face, three-stage, 47-mm-diameter, polycarbonate filterpack housing was loaded with a quartzfiber (Pallflex 2500 QAT-UP) particle filter followed by tandem rayon filters (Schleicher and Schuell, $8 \mathrm{~S}$ ) impregnated with a solution of $10 \% \mathrm{~K}_{2} \mathrm{CO}_{3}$ and $10 \%$ glycerol (Bardwell et al., 1990). Based on independent analysis of the tandem filters, both analytes were sampled at $98 \%$ efficiency. Filterpacks were cleaned, dried, loaded, and unloaded in a class 100 clean bench configured with impregnated filters on the inlet to remove alkaline- and acidicreactive trace gases. Exposed filters were transferred to polypropylene tubes, stored in glass jars, frozen, and express shipped from Cape Town to Mount Washington Observatory (MWO) where they were analyzed by IC. The average precision for $\mathrm{Br}_{t}$ was $\pm 5 \%$ or $\pm 0.05 \mathrm{pmol} \mathrm{Br} \mathrm{mol}^{-1}$, whichever was the greater absolute value, and the corresponding DL was $0.10 \mathrm{pmol} \mathrm{Br} \mathrm{mol}^{-1}$. The average precision for $\mathrm{SO}_{2}$ was $\pm 8 \%$ or $\pm 0.5 \mathrm{pmol} \mathrm{mol}^{-1}$, whichever was greater, and the corresponding DL was $1.0 \mathrm{pmol} \mathrm{mol}^{-1}$.

\subsubsection{Aerosols}

Ambient aerosols were sampled over discrete daytime and nighttime intervals using a modified Graseby-Anderson Model 235 cascade impactor configured with a Liu-Pui type inlet, precleaned polycarbonate substrates, and quartzfiber backup filters (Pallflex 2500 QAT-UP) (Pszenny et al., 2004; Keene et al., 2007a). At an average sampling rate of $0.78 \mathrm{~m}^{3} \mathrm{~min}^{-1}$, the average $50 \%$ aerodynamic cut diameters for the impaction stages were $20,11,4.3,2.5$, 1.2 , and $0.65 \mu \mathrm{m}$ yielding average geometric mean diameters (GMDs) for the size-resolved samples of 29, 15, 7.0, $3.3,1.8,0.89$, and $0.46 \mu \mathrm{m}$. Bulk aerosol was sampled in parallel on quartz-fiber filters at an average flow rate of $1.1 \mathrm{~m}^{3} \mathrm{~min}^{-1}$. Impactors and bulk-filter cassettes were cleaned, dried, loaded, and unloaded in a Class 100 clean bench configured as described above. Exposed substrates and filters were halved, transferred to polypropylene tubes, sealed in glass mason jars, frozen, and express shipped from Cape Town to MWO for analysis.

Half sections of each substrate were extracted in $13 \mathrm{ml}$ deionized water using a mini vortexer and sonication; half sections of exposed backup and bulk filters were similarly extracted in $40 \mathrm{ml}$ deionized water. Substrate and filter extracts were analyzed by IC for total (ionized + undissociated) $\mathrm{Cl}^{-}, \mathrm{Br}^{-}, \mathrm{SO}_{4}^{2-}, \mathrm{CH}_{3} \mathrm{SO}_{3}^{-}, \mathrm{HCOO}^{-}, \mathrm{CH}_{3} \mathrm{COO}^{-}, \mathrm{C}_{2} \mathrm{O}_{4}^{2-}$, $\mathrm{NO}_{3}^{-}, \mathrm{NH}_{4}^{+}, \mathrm{Na}^{+}, \mathrm{K}^{+}$, and $\mathrm{Mg}^{2+}$ (Keene et al., 2004). 
Table 1. Start and stop dates, times, and positions for the four transport regimes.

\begin{tabular}{lcccc}
\hline & EURO & N-AFR & ITCZ & S-ATL \\
\hline Start date, UTC & 23 Oct & 29 Oct & $3 \mathrm{Nov}$ & $5 \mathrm{Nov}$ \\
Start time, hhmm UTC & $06: 29$ & $07: 40$ & $07: 21$ & $18: 36$ \\
Stop date, UTC & 27 Oct & $3 \mathrm{Nov}$ & $5 \mathrm{Nov}$ & $10 \mathrm{Nov}$ \\
Stop time, hh:mm UTC & $03: 34$ & $07: 21$ & $18: 36$ & $20: 35$ \\
Start latitude, deg & $51.37 \mathrm{~N}$ & $32.79 \mathrm{~N}$ & $9.98 \mathrm{~N}$ & $1.36 \mathrm{~N}$ \\
Start longitude, deg & $1.94 \mathrm{E}$ & $14.07 \mathrm{~W}$ & $19.98 \mathrm{~W}$ & $12.77 \mathrm{~W}$ \\
Stop latitude, deg & $43.40 \mathrm{~N}$ & $9.98 \mathrm{~N}$ & $1.36 \mathrm{~N}$ & $17.77 \mathrm{~S}$ \\
Stop longitude, deg & $9.82 \mathrm{~W}$ & $19.98 \mathrm{~W}$ & $12.77 \mathrm{~W}$ & $4.37 \mathrm{E}$ \\
\hline
\end{tabular}

The corresponding average DLs for bulk samples were 0.8 , $0.002,0.1,0.02,0.4,0.1,0.006,0.04,1.1,2.6,0.6$, and $0.2 \mathrm{nmol} \mathrm{m}^{-3}$, respectively; those for the GMD $0.46-\mu \mathrm{m}$ size fraction were $1.0,0.002,0.2,0.03,0.6,0.2,0.009,0.05,0.5$, $3.5,0.8,0.3 \mathrm{nmol} \mathrm{m}^{-3}$, respectively; and those for the larger individual size fractions were $0.09,0.001,0.01,0.007,0.07$, $0.09,0.006,0.01,0.001,0.1,0.06$, and $0.01 \mathrm{nmol} \mathrm{m}^{-3}$, respectively.

Internal losses of super- $\mu \mathrm{m}$ aerosols within slotted cascade impactors of this type average about $25 \%$ to $30 \%$ (e.g. Willeke et al., 1975); other sources of bias for size-resolved particulate analytes based on the above procedures are generally unimportant (Keene et al., 1990). Sea-salt and non-seasalt (nss) constituents were differentiated using $\mathrm{Na}^{+}$as the reference species (Keene et al., 1986). Departures from seasalt composition are reported as both absolute deficits and enrichment factors (EFs) relative to sea salt (e.g., Sander et al., 2003). Reported concentrations of total particulate $\mathrm{Br}^{-}$, $\mathrm{Na}^{+}$, and $\mathrm{nss} \mathrm{SO}_{4}^{2-}$ are based on aerosol sampled in bulk. Because they are not conservative in bulk samples, reported concentrations of total particulate $\mathrm{Cl}^{-}, \mathrm{NO}_{3}^{-}$, and $\mathrm{NH}_{4}^{+}$are based on values summed over all size fractions sampled with the cascade impactor.

\subsubsection{Meteorological conditions and ancillary data}

Air and sea-surface temperature, relative humidity (RH), pressure, and wind speed and direction were measured continuously with instruments maintained by the ship's crew and compiled as one-minute averages (posted at http://dship.awi. de/polarstern/index.htm). Temperature and RH were periodically measured in parallel with a sling psychrometer operated adjacent to the inlets for our samplers; results were statistically indistinguishable from those reported by the ship. $\mathrm{O}_{3}$ and $\mathrm{CO}$ were measured continuously by the University of York and compiled as 10-min averages (L. Carpenter, University of York, unpublished data, 2008). MBL depth was estimated from 1) profiles of virtual potential temperature derived from rawinsondes launched from the ship at 12:00 UTC on most days and at other times on some days, 2) the lowest cloud base measured by a ceilometer operated by the ship's crew, and 3) either the first significant drop in back scatter or the lowest cloud layer detected with a lidar operated during the cruise (Immler and Schrems, 2006).

\subsection{Atmospheric transport}

Large-scale atmospheric transport was evaluated using both HYbrid Single-Particle Lagrangian Integrated Trajectories (HYSPLIT, Fig. 1) (Draxler et al., 2005) and Lagrangian particle dispersion (FLEXPART) retroplumes (Stohl et al., 2005). Trajectories were initialized at 500 and $1000 \mathrm{~m}$ above the sea surface. Samples were classified into four major transport regimes (described in more detail below) based on visual inspection of the back trajectories, the corresponding column and footprint residence time components of the retroplumes, and local meteorology (Fischer et al., 2006). Samples collected at transitions between regimes were assigned to the regime that corresponded to the greater fraction of sampling time. The regimes are broadly characterized as European influenced (hereafter referred to as EURO), North African influenced (N-AFR), the inter-tropical convergence zone (ITCZ), and South-Atlantic influenced (S-ATL). Start and stop dates, times, and positions for each regime are listed in Table 1.

\subsection{Calculations}

Aerosol $\mathrm{pH}$ was inferred based on the measured phase partitioning and associated thermodynamic properties (Henry's Law and dissociation constants) of $\mathrm{HCl}$, meteorological conditions (RH and temperature), and hygroscopicity models of aerosol liquid water content (LWC) (Keene et al., 2004). Dry-deposition fluxes of size-resolved particulatephase species to the surface ocean were calculated based on the measured chemical composition and GMD for each size fraction, wind velocity, air temperature, and RH following Hummelshøj et al. (1992). The laminar sublayer was assumed to be at $98 \%$ RH (Lewis and Schwartz, 2004) and the corresponding GMD for each size fraction within the sublayer was based on the measured ionic composition and hygroscopicity models (the same as those used to estimate aerosol LWC in the overlying air; see above). At steady state in the absence of precipitation, dry-deposition fluxes of sea-salt aerosol are balanced by the corresponding emission fluxes. Emission fluxes of particulate $\mathrm{Cl}^{-}$and $\mathrm{Br}^{-}$associated with sea-salt aerosol were inferred from the calculated dry-deposition fluxes of sea-salt $\mathrm{Na}^{+}$and the corresponding concentration ratios in surface seawater (Keene et al., 2007a). Dry-deposition fluxes of $\mathrm{HCl}, \mathrm{Br}_{t}, \mathrm{HNO}_{3}, \mathrm{NH}_{3}$, and $\mathrm{SO}_{2}$ to the surface ocean were calculated based on the measured mixing ratios, wind speed, air temperature, and surface-ocean-water temperature following Valigura (1995). This approach assumes that the surface ocean is undersaturated with respect to the gas phase and, thus, solubility 
does not limit corresponding dry-deposition fluxes. We also assume no vertical gradients in particulate- and gas-phase species between the reference height for these approaches $(10 \mathrm{~m})$ and the measurement height. As described in detail below, the dry-deposition fluxes of size-resolved aerosols and soluble gases calculated from measurements based on the above approaches were used to parameterize turnover rates for aerosols and exogenous source strengths for $\mathrm{N}$ and $\mathrm{S}$ gases in the model.

\subsection{Photochemical-box-model simulations}

Multiphase chemical processes involving inorganic halogens within each of the four major transport regimes were simulated with the photochemical box model MECCA (Model Efficiently Calculating Chemistry of the Atmosphere) using the Rosenbrock 3 positive-definite solver (Sander et al., 2005; Sandu and Sander, 2006). The principal goal of this component of the analysis was to evaluate our current understanding of the underlying processes as described in the model based on the degree of consistency between measured and simulated characteristics of the system. MECCA contains a comprehensive atmospheric reaction mechanism that includes transformations involving: 1) $\mathrm{O}_{3}, \mathrm{CH}_{4}, \mathrm{HO}_{\mathrm{x}}$, and $\mathrm{NO}_{\mathrm{x}}$; 2) non-methane hydrocarbons (NMHCs); 3) halogens ( $\mathrm{Cl}, \mathrm{Br}$, I); and 4) sulfur. Because iodine and NMHC species were not measured during the cruise, their reactions were switched off for these simulations. In addition to gas-phase reactions, the scheme includes fully integrated multiphase transformations involving both aqueous-phase and heterogeneous pathways. Unlike previous versions of MECCA which considered only two aerosol size bins, a recent model version (Sander et al., 2009) was used in this study to simulate multiple aerosol size bins. Mass transfer is calculated dynamically and does not assume Henry's Law equilibrium conditions (see supplementary material, Table S1 for a complete description of the chemical scheme, http://www.atmos-chem-phys.net/9/ 7361/2009/acp-9-7361-2009-supplement.pdf). Photochemical reaction rates vary as a function of solar zenith angle under clear-sky conditions. For each simulation, the model was parameterized and initialized based on median values for measurements associated with the corresponding transport regime (Table 2). To minimize sources of variability among results for different regimes, the MBL depth for each simulation was set to the median value for the entire cruise (Table 2). For species that were not measured, reasonable initial conditions were assumed. In all simulations, we assumed a constant $\mathrm{O}_{3}$ entrainment flux from the free troposphere of $5 \times 10^{10}$ molecules $\mathrm{cm}^{-2} \mathrm{~s}^{-1}$ (Thompson and Zafiriou, 1983). Mixing ratios of $\mathrm{CH}_{4}$ were held constant (i.e., exogenous sources were assumed equal to internal sinks).

The model was initialized with externally mixed populations of unreacted sea salt and pre-existing nss $\mathrm{S}$ aerosols. The number $(\mathrm{N}=7)$ and sizes of sea-salt bins in the model
(Table 2) corresponded to the size fractions sampled by the impactor. A single additional bin (diameter $=0.18 \mu \mathrm{m}$ ) contained all preexisting nss $\mathrm{S}$. The liquid water content, salinity, and lifetime against dry deposition for each aerosol size bin were calculated off-line. Dry-deposition velocities for gasphase species were also calculated off-line. Size-resolved emission fluxes of sea salt for each regime were set equal to the corresponding median values for size-resolved drydeposition fluxes thereby maintaining constant concentrations and size distributions of conservative particulate-phase constituents during each simulation. At each time step, reacted aerosol was removed from, and an equivalent amount of fresh aerosol was added to, each bin in proportion to the corresponding lifetime of aerosol within that bin.

Vertical profiles of sea salt within the MBL vary as a function of particle size and, thus, the atmospheric lifetimes of sea-salt aerosol within each size bin varied as a function of the corresponding vertical mixing potential (e.g., Lewis and Schwartz, 2004). Consequently, the height to which particles are mixed must be considered explicitly to properly parameterize turnover rates of size-resolved aerosols within the 0-D domain. For each regime, the steady-state vertical profiles of size-resolved sea salt mass within each size bin were estimated assuming neutrally stable conditions based on a power-law relationship (Lewis and Schwartz, 2004) parameterized for the corresponding median meteorological conditions and size-resolved concentrations measured at $23 \mathrm{~m}$ (Table 2). Coefficients were calculated to scale nearsurface measurements of size-resolved aerosols to mean concentrations over the vertical profiles (Table 2). The liquid water content of each size bin at $23 \mathrm{~m}$ was multiplied by the corresponding scaling coefficient to yield a columnaveraged value. The atmospheric lifetime against dry deposition for each bin was then calculated directly (columnaveraged value/dry-deposition rate). The atmospheric lifetime of the size bin containing preexisting nss $\mathrm{SO}_{4}^{2-}$ was assumed equal to that of the smallest sea-salt size bin. We note that, relative to predictions based on theoretical considerations (Lewis and Schwartz, 2004), the limited available measurements of vertical profiles in bulk sea-salt mass (Blanchard et al., 1984; Maring et al., 2003) indicate substantially greater vertical gradients within the MBL. If these measured profiles are generally representative of conditions within the MBL along the cruise track, turnover rates for sea salt and associated reaction products in the model calculations were underestimated.

At each time step, a mixture of $\mathrm{HNO}_{3}$ and $\mathrm{NO}_{2}$ was added to the system at a combined rate equal to the corresponding median loss rate of oxidized $\mathrm{N}\left(\mathrm{HNO}_{3}\right.$ + particulate $\mathrm{NO}_{3}^{-}$, hereafter referred to as total $\mathrm{NO}_{3}$ ) via dry deposition (calculated from measurements as described in Sect. 2.4). Although the total exogenous source flux of oxidized $\mathrm{N}$ was reasonably well constrained by the corresponding drydeposition fluxes, the relative amounts of $\mathrm{HNO}_{3}$ to $\mathrm{NO}_{\mathrm{x}}$ in the source varied spatially along the cruise track in response 
Table 2. Model parameterization and initialization. Unless otherwise noted, the model was parameterized and initialized based on median values for measured and calculated results from the cruise.

\begin{tabular}{|c|c|c|c|c|c|}
\hline Parameter & Units & EURO & N-AFR & ITCZ & S-ATL \\
\hline Date & dd-mmm-yy & 25-Oct-03 & 31-Oct-03 & 4-Nov-03 & 8-Nov-03 \\
\hline Latitude & Degrees & $48 \mathrm{~N}$ & $21 \mathrm{~N}$ & $6 \mathrm{~N}$ & $9 \mathrm{~S}$ \\
\hline Temperature & ${ }^{\circ} \mathrm{C}$ & 11.4 & 23.2 & 27.0 & 22.5 \\
\hline $\mathrm{RH}$ & $\%$ & 56.1 & 67.6 & 78.4 & 77.3 \\
\hline Wind Velocity & $\mathrm{ms}^{-1}$ & 7.3 & 8.5 & 3.5 & 8.1 \\
\hline MBL Height $^{\mathrm{a}}$ & $\mathrm{m}$ & 912 & 912 & 912 & 912 \\
\hline \multicolumn{6}{|l|}{ Aerosol size bins ${ }^{b}$} \\
\hline Bin $1 \mathrm{Na}^{+}$at $23 \mathrm{~m}$ & $\mathrm{nmol} \mathrm{m}^{-3}$ & 30.4 & 74.0 & 4.4 & 6.8 \\
\hline Bin $2 \mathrm{Na}^{+}$at $23 \mathrm{~m}$ & $\mathrm{nmol} \mathrm{m}^{-3}$ & 45.8 & 132.0 & 7.0 & 12.4 \\
\hline Bin $3 \mathrm{Na}^{+}$at $23 \mathrm{~m}$ & $\mathrm{nmol} \mathrm{m}^{-3}$ & 44.3 & 106.0 & 16.1 & 27.9 \\
\hline Bin $4 \mathrm{Na}^{+}$at $23 \mathrm{~m}$ & $\mathrm{nmol} \mathrm{m}^{-3}$ & 12.7 & 42.9 & 11.3 & 21.9 \\
\hline Bin $5 \mathrm{Na}^{+}$at $23 \mathrm{~m}$ & $\mathrm{nmol} \mathrm{m}^{-3}$ & 10.9 & 29.7 & 7.7 & 17.0 \\
\hline Bin $6 \mathrm{Na}^{+}$at $23 \mathrm{~m}$ & $\mathrm{nmol} \mathrm{m}^{-3}$ & 3.5 & 9.3 & 1.9 & 4.5 \\
\hline $\operatorname{Bin} 7 \mathrm{Na}^{+}$at $23 \mathrm{~m}$ & $\mathrm{nmol} \mathrm{m}^{-3}$ & 1.4 & 3.2 & 1.8 & 1.3 \\
\hline $\mathrm{Bin} 8 \mathrm{nss} \mathrm{SO}_{4}^{2-}$ at $23 \mathrm{~m}$ & $\mathrm{nmol} \mathrm{m}^{-3}$ & 15.1 & 13.4 & 8.4 & 9.6 \\
\hline Bin 1 Vertical Scaling Coeff. ${ }^{c}$ & & 0.46 & 0.52 & 0.19 & 0.50 \\
\hline Bin 2 Vertical Scaling Coeff. ${ }^{c}$ & & 0.79 & 0.82 & 0.61 & 0.81 \\
\hline Bin 3 Vertical Scaling Coeff. ${ }^{c}$ & & 0.93 & 0.94 & 0.88 & 0.94 \\
\hline Bin 4 Vertical Scaling Coeff. ${ }^{\mathrm{c}}$ & & 0.97 & 0.97 & 0.95 & 0.97 \\
\hline Bin 5 Vertical Scaling Coeff. ${ }^{c}$ & & 0.97 & 0.97 & 0.97 & 0.97 \\
\hline Bin 6 Vertical Scaling Coeff. ${ }^{c}$ & & 0.97 & 0.97 & 0.97 & 0.97 \\
\hline Bin 7 Vertical Scaling Coeff. ${ }^{c}$ & & 0.98 & 0.98 & 0.97 & 0.97 \\
\hline Bin 8 Vertical Scaling Coeff. ${ }^{c}$ & & 1.00 & 1.00 & 1.00 & 1.00 \\
\hline Bin 1 Dry-Deposition Velocity & $\mathrm{cm} \mathrm{s}^{-1}$ & $6.1 \mathrm{E}+000$ & $5.7 \mathrm{E}+000$ & $5.9 \mathrm{E}+000$ & $5.2 \mathrm{E}+000$ \\
\hline Bin 2 Dry-Deposition Velocity & $\mathrm{cm} \mathrm{s}^{-1}$ & $2.0 \mathrm{E}+000$ & $2.1 \mathrm{E}+000$ & $1.4 \mathrm{E}+000$ & $2.0 \mathrm{E}+000$ \\
\hline Bin 3 Dry-Deposition Velocity & $\mathrm{cm} \mathrm{s}^{-1}$ & $1.1 \mathrm{E}+000$ & $1.3 \mathrm{E}+000$ & $5.2 \mathrm{E}-001$ & $1.2 \mathrm{E}+000$ \\
\hline Bin 4 Dry-Deposition Velocity & $\mathrm{cm} \mathrm{s}^{-1}$ & $8.9 \mathrm{E}-001$ & $1.1 \mathrm{E}+000$ & $3.2 \mathrm{E}-001$ & $1.0 \mathrm{E}+000$ \\
\hline Bin 5 Dry-Deposition Velocity & $\mathrm{cm} \mathrm{s}^{-1}$ & $8.0 \mathrm{E}-001$ & $1.0 \mathrm{E}+000$ & $5.5 \mathrm{E}-002$ & $9.7 \mathrm{E}-001$ \\
\hline Bin 6 Dry-Deposition Velocity & $\mathrm{cm} \mathrm{s}^{-1}$ & $1.7 \mathrm{E}-001$ & $5.7 \mathrm{E}-001$ & $1.9 \mathrm{E}-002$ & $4.1 \mathrm{E}-001$ \\
\hline Bin 7 Dry-Deposition Velocity & $\mathrm{cm} \mathrm{s}^{-1}$ & $1.6 \mathrm{E}-002$ & $2.0 \mathrm{E}-002$ & $1.2 \mathrm{E}-002$ & $1.8 \mathrm{E}-002$ \\
\hline Bin 8 Dry-Deposition Velocity & $\mathrm{cm} \mathrm{s}^{-1}$ & $1.6 \mathrm{E}-002$ & $2.0 \mathrm{E}-002$ & $1.2 \mathrm{E}-002$ & $1.8 \mathrm{E}-002$ \\
\hline Gas Dry-Deposition Velocity & $\mathrm{cm} \mathrm{s}^{-1}$ & $1.1 \mathrm{E}+000$ & $1.1 \mathrm{E}+000$ & $6.8 \mathrm{E}-001$ & $1.0 \mathrm{E}+000$ \\
\hline \multicolumn{6}{|l|}{ Inputs from Exogenous Sources } \\
\hline $\mathrm{O}_{3}$ & molec $\mathrm{cm}^{-2} \mathrm{~s}^{-1}$ & $5.0 \mathrm{E}+010$ & $5.0 \mathrm{E}+010$ & $5.0 \mathrm{E}+010$ & $5.0 \mathrm{E}+010$ \\
\hline $\mathrm{NO}_{2}$ & molec $\mathrm{cm}^{-2} \mathrm{~s}^{-1}$ & $1.7 \mathrm{E}+010$ & $3.0 \mathrm{E}+009$ & $1.0 \mathrm{E}+009$ & $1.6 \mathrm{E}+009$ \\
\hline $\mathrm{HNO}_{3}$ & molec $\mathrm{cm}^{-2} \mathrm{~s}^{-1}$ & $1.7 \mathrm{E}+010$ & $1.5 \mathrm{E}+010$ & $1.0 \mathrm{E}+009$ & $6.5 \mathrm{E}+009$ \\
\hline$\left(\mathrm{CH}_{3}\right)_{2} \mathrm{~S}+\mathrm{SO}_{2}$ & molec $\mathrm{cm}^{-2} \mathrm{~s}^{-1}$ & $8.5 \mathrm{E}+009$ & $6.5 \mathrm{E}+009$ & $2.0 \mathrm{E}+009$ & $2.4 \mathrm{E}+009$ \\
\hline $\mathrm{NH}_{3}$ & molec $\mathrm{cm}^{-2} \mathrm{~s}^{-1}$ & $6.3 \mathrm{E}+009$ & $1.5 \mathrm{E}+009$ & $3.0 \mathrm{E}+009$ & $1.6 \mathrm{E}+009$ \\
\hline \multicolumn{6}{|l|}{ Initial Conditions ${ }^{\mathrm{d}}$} \\
\hline $\mathrm{NO}_{2}^{\mathrm{e}}$ & $\mathrm{mol} \mathrm{mol}^{-1}$ & $2.0 \mathrm{E}-011$ & $2.0 \mathrm{E}-011$ & $2.0 \mathrm{E}-011$ & $2.0 \mathrm{E}-011$ \\
\hline $\mathrm{CH}_{4}^{\mathrm{e}, \mathrm{f}}$ & $\mathrm{mol} \mathrm{mol}^{-1}$ & $1.8 \mathrm{E}-006$ & $1.8 \mathrm{E}-006$ & $1.8 \mathrm{E}-006$ & $1.8 \mathrm{E}-006$ \\
\hline $\mathrm{HCHO}^{\mathrm{e}}$ & $\mathrm{mol} \mathrm{mol}^{-1}$ & $3.0 \mathrm{E}-010$ & $3.0 \mathrm{E}-010$ & $3.0 \mathrm{E}-010$ & $3.0 \mathrm{E}-010$ \\
\hline $\mathrm{CO}$ & $\mathrm{mol} \mathrm{mol}^{-1}$ & $1.4 \mathrm{E}-007$ & $1.1 \mathrm{E}-007$ & $9.9 \mathrm{E}-008$ & $7.7 \mathrm{E}-008$ \\
\hline$\left(\mathrm{CH}_{3}\right)_{2} \mathrm{~S}^{\mathrm{e}}$ & $\mathrm{mol} \mathrm{mol}^{-1}$ & $6.0 \mathrm{E}-011$ & $6.0 \mathrm{E}-011$ & $6.0 \mathrm{E}-011$ & $6.0 \mathrm{E}-011$ \\
\hline $\mathrm{H}_{2} \mathrm{O}_{2}^{\mathrm{e}}$ & $\mathrm{mol} \mathrm{mol}^{-1}$ & $6.0 \mathrm{E}-010$ & $6.0 \mathrm{E}-010$ & $6.0 \mathrm{E}-010$ & $6.0 \mathrm{E}-010$ \\
\hline $\mathrm{CH}_{3} \mathrm{OH}^{\mathrm{e}}$ & $\mathrm{mol} \mathrm{mol}^{-1}$ & $3.0 \mathrm{E}-010$ & $3.0 \mathrm{E}-010$ & $3.0 \mathrm{E}-010$ & $3.0 \mathrm{E}-010$ \\
\hline
\end{tabular}

\footnotetext{
a The actual median MBL depths for EURO, N-AFR, ITCZ, and S-AFR regimes were 1224, 951, 658, and 873 m, respectively (see Sect. 2.5 ).

$\mathrm{b}$ The ambient geometric mean diameters for aerosol size bins 1 through 8 were $28.8,15.2,7.08,3.32,1.75,0.89,0.46$, and $0.18 \mu$ m, respectively.

c Based on Lewis and Schwartz (2004) (see text).

${ }^{\mathrm{d}} \mathrm{HCl}, \mathrm{HNO}_{3}, \mathrm{SO}_{2}, \mathrm{NH}_{3}$, and $\mathrm{O}_{3}$ for each regime were initialized based on the median measured mixing ratios (Table 3 ).

e Assumed value.

${ }^{\mathrm{f}}$ Held constant during simulation (exogenous sources assumed equal to internal sinks)

Scientific notation refers to the power 10 ; for example, $3.0 \mathrm{E}-010$ is $3.0 \times 10^{-10}$.
} 
to variability in the relative importance of distinct and poorly characterized processes. $\mathrm{NO}_{\mathrm{x}}$ and $\mathrm{HNO}_{3}$ within the MBL have relatively short lifetimes (less than one to two days) against oxidation and deposition, respectively, and, consequently, the importance of transport within the MBL as a source for oxidized $\mathrm{N}$ from continental sources decreases rapidly with distance from coasts (e.g., Neuman et al., 2006). Potentially important sources for oxidized $\mathrm{N}$ in the more remote open-ocean MBL along the cruise track include entrainment of a time-varying mixture of combustion-and lightningderived $\mathrm{HNO}_{3}$ and $\mathrm{NO}_{\mathrm{x}}$ from the free troposphere (Neuman et al., 2006, Shepon et al., 2007), direct emissions of NO from ships at sea (Corbett et al., 1999), transport and thermal decomposition of $\mathrm{NO}_{\mathrm{x}}$ reservoir species such as peroxyacetyl nitrate (PAN; Jacobi et al., 1999), and chemical degradation of alkyl nitrates emitted from the surface ocean (Dahl et al., 2005). Because spatial variability in the speciation and relative importance of different sources along the cruise track could not be evaluated explicitly, the model was parameterized by adjusting the $\mathrm{HNO}_{3}: \mathrm{NO}_{2}$ ratio in the oxidized $\mathrm{N}$ source term for each regime such that corresponding simulated steady-state mixing ratios of $\mathrm{NO}_{\mathrm{x}}$ in the model runs that included transformations involving halogens fell within the range of available measurements in the eastern Atlantic MBL (e.g., Carsey et al., 1997; Leser et al., 2003; Lawler et al., 2009; Lee et al., 2009). Resulting $\mathrm{HNO}_{3}: \mathrm{NO}_{2}$ ratios in the source terms for the EURO (1:1), N-AFR (5:1), ITCZ (1:1), and S-ATL (4:1) regimes yielded steady-state mixing ratios of $\mathrm{NO}_{\mathrm{x}}$ averaging $171,31,8$, and $20 \mathrm{pmol} \mathrm{mol}^{-1}$, respectively. The implications of this parameterization scheme are discussed below.

$\left(\mathrm{CH}_{3}\right)_{2} \mathrm{~S}$ emissions were based on the WCRP/IGAC emissions inventory (Roelofs, et al., 1998). $\mathrm{SO}_{2}$ was added at rates such that $\mathrm{SO}_{2}+\left(\mathrm{CH}_{3}\right)_{2} \mathrm{~S}$ inputs equaled the corresponding median losses of total nss $\mathrm{S}\left(\mathrm{SO}_{2}+\mathrm{nss}_{4} \mathrm{SO}_{4}^{2-}\right)$ via dry deposition for each regime. For the ITCZ, the calculated median dry-deposition flux of total nss $\mathrm{S}$ was less than the corresponding $\left(\mathrm{CH}_{3}\right)_{2} \mathrm{~S}$ emissions predicted by the inventory. For this regime, the source term was set equal to the inventory prediction (i.e., the flux of $\mathrm{SO}_{2}$ from other exogenous sources was assumed to be zero). $\mathrm{NH}_{3}$ was added to the system at rates equal to the corresponding median losses of total reduced $\mathrm{N}\left(\mathrm{NH}_{3}\right.$ + particulate $\left.\mathrm{NH}_{4}^{+}\right)$via dry deposition for each regime. Inputs of $\mathrm{N}$ and $\mathrm{S}$ from exogenous sources for each regime are summarized in Table 2. The above approach sustained essentially constant steady-state concentrations of total reactive $\mathrm{N}$ and $\mathrm{S}$ during each simulation.

Our analysis focused primarily on two sets of conditions that were simulated for each of the four regimes. One set (hereafter referred to as "with halogens") included the full suite of transformations involving inorganic $\mathrm{Cl}$ and $\mathrm{Br}$ species. For the other set (hereafter referred to as "no halogens"), each regime was parameterized and initialized with the same conditions employed for the corresponding "with halogens" run but all transformations involving halogens were switched off (i.e., $\mathrm{Cl}^{-}$and $\mathrm{Br}^{-}$associated with nascent marine aerosols were chemically inert). To achieve steady state conditions for each simulation, the model was run over a period of 110 days preceding the end point of the corresponding observation period within that flow regime. Results from the last several days of each simulation were interpreted. In addition to the primary simulations described above, the model was run over ranges of conditions to evaluate the sensitivity of results to (1) the approach employed to vertically scale size-resolve aerosols and (2) variability in the ratio of $\mathrm{HNO}_{3}$ to $\mathrm{NO}_{2}$ in the source term. Results of these runs are briefly discussed where appropriate below. The simulations provide useful insight concerning the underlying processes. As discussed in more detail below, however, some important aspects of the MBL system (including entrainment rates, the sources and photochemical ages of oxidized N, and mixing ratios of halogen radicals and precursors in ambient air) were poorly constrained by observation. In addition, current models do not reproduce some measured characteristics of the multiphase system, which suggests that they are missing some important processes. Finally, these box model calculations do not consider physicochemical dynamics driven by transformations involving iodine compounds, vertical mixing, non-steady-state conditions, or cloud processing. Consequently, the simulated results may not be representative of ambient conditions in some respects.

\section{Results and discussion}

\subsection{Atmospheric-transport regimes}

The EURO regime was associated with northwesterly flow that had recently (less than one day prior to sampling) passed over Western Europe (Fig. 1), variable near-surface wind velocities (median $=7.3 \mathrm{~m} \mathrm{~s}^{-1}$ ), and relatively low temperatures $\left(\right.$ median $\left.=11.4^{\circ} \mathrm{C}\right)$ and RHs (median $=56.1 \%$ ) (Fig. 2). The N-AFR regime was characterized by more northerly transport with a long (several day) fetch over the eastern North Atlantic Ocean before passing near or over western North Africa prior to sampling, the highest median wind velocity $\left(8.5 \mathrm{~m} \mathrm{~s}^{-1}\right)$, and increasing temperatures (me$\operatorname{dian}=23.2^{\circ} \mathrm{C}$ ) and RHs (median $=67.6 \%$ ). The transition from the Northern to Southern Hemisphere through the ITCZ was characterized by shifting air flow from northerly to southerly, low wind velocities (median $=3.5 \mathrm{~m} \mathrm{~s}^{-1}$ ), widely scattered showers, and relatively high temperatures (me$\operatorname{dian}=27.0^{\circ} \mathrm{C}$ ) and RHs (median=78.4\%). The S-ATL regime was characterized by persistent southeasterly flow with long fetch over the eastern South Atlantic Ocean roughly parallel to the coast of southern Africa, moderate wind velocities (median $\left.=8.1 \mathrm{~m} \mathrm{~s}^{-1}\right)$, and decreasing temperatures $\left(\right.$ median $\left.=22.5^{\circ} \mathrm{C}\right)$ and RHs $($ median $=77.3 \%)$.

The major physicochemical characteristics of MBL air along the cruise track (Figs. 2, 3; Williams et al., 2007) 


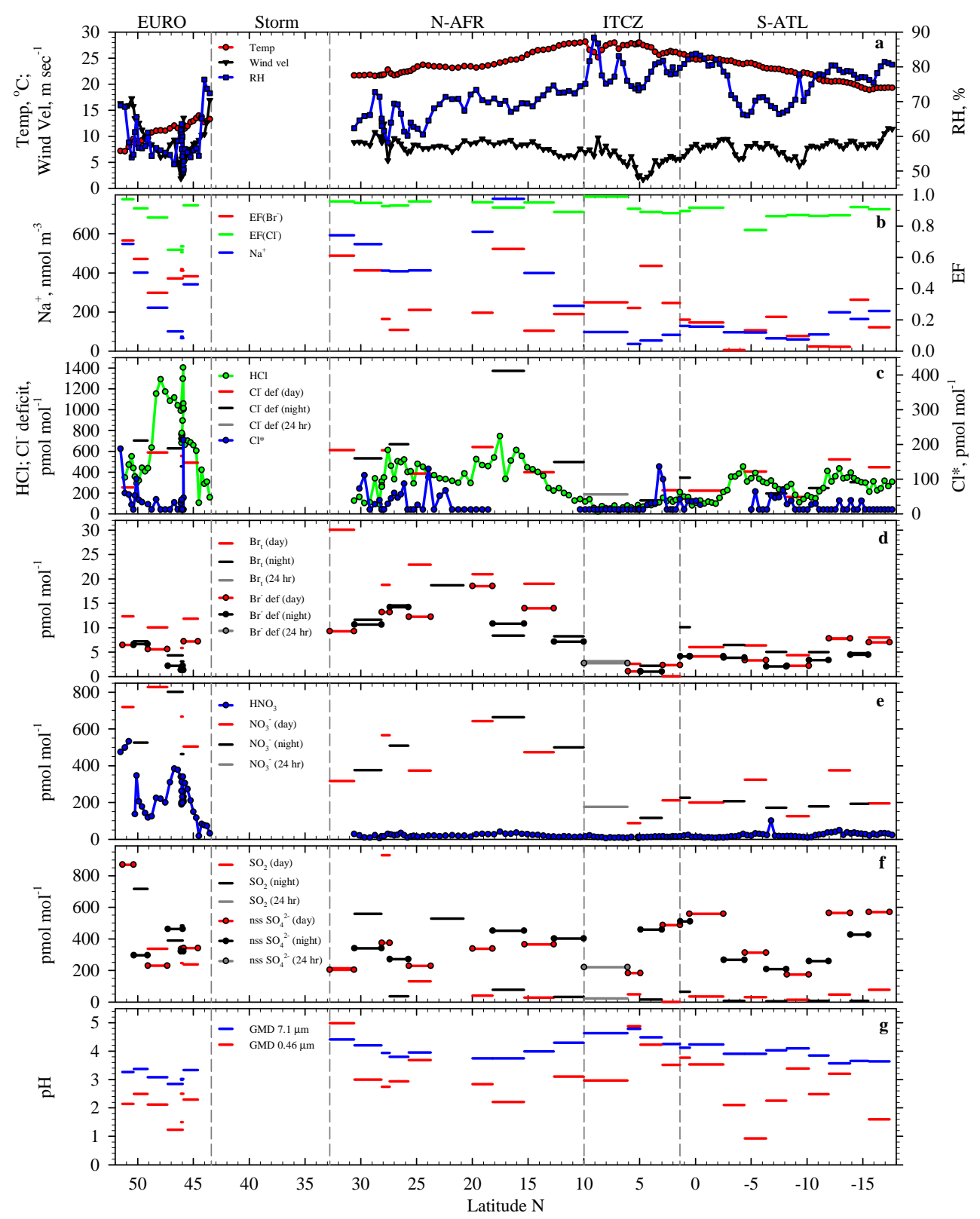

Fig. 2. Latitudinal variability in measured and directly calculated characteristics of near-surface air including (a) temperature, RH, and wind velocity averaged over each mist-chamber sampling interval; (b) particulate $\mathrm{Na}^{+}, \mathrm{EF}\left(\mathrm{Cl}^{-}\right)$, and $\mathrm{EF}\left(\mathrm{Br}^{-}\right)$; $(\mathbf{c}) \mathrm{HCl}, \mathrm{Cl}^{*}$, and particulate $\mathrm{Cl}^{-}$ deficit; (d) $\mathrm{Br}_{t}$ and particulate $\mathrm{Br}^{-}$deficit; (e) $\mathrm{HNO}_{3}$ and particulate $\mathrm{NO}_{3}^{-}$; (f) $\mathrm{SO}_{2}$ and particulate nss $\mathrm{SO}_{4}^{2-}$; and (g) $\mathrm{pH}_{\text {of }} \mathrm{GMD} 7.1-\mu \mathrm{m}$ and GMD $0.46-\mu \mathrm{m}$ aerosol size fractions inferred from the measured $\mathrm{HCl}$ phase partitioning. In panel $\mathrm{f}, \mathrm{SO}_{2}$ during the first sampling interval $\left(2277 \mathrm{pmol} \mathrm{mol}^{-1}\right)$ is off scale. Values below DLs are plotted as $0.5 *$ DLs. Vertical dashed lines partition major transport regimes.

varied substantially both within and among transport regimes as functions of upwind emissions of precursors, length and duration of fetch over the ocean, associated meteorological drivers (primarily wind velocity and $\mathrm{RH}$ ), and chemical processing. In the following sections we evaluate the relative influences of these factors on the cycling of inorganic halogens and related species for each regime.

\subsection{European influenced}

\subsubsection{Measured characteristics}

The relatively high concentrations of $\mathrm{HNO}_{3}$, particulate $\mathrm{NO}_{3}^{-}$, and $\mathrm{SO}_{2}$ (Figs. 2e, f, 3n, Table 3) measured in the EURO regime reflect $\mathrm{NO}$ and $\mathrm{SO}_{2}$ emissions from widespread fossil-fuel combustion across Western Europe and from heavy ship traffic in the surrounding ocean. Sea-salt 

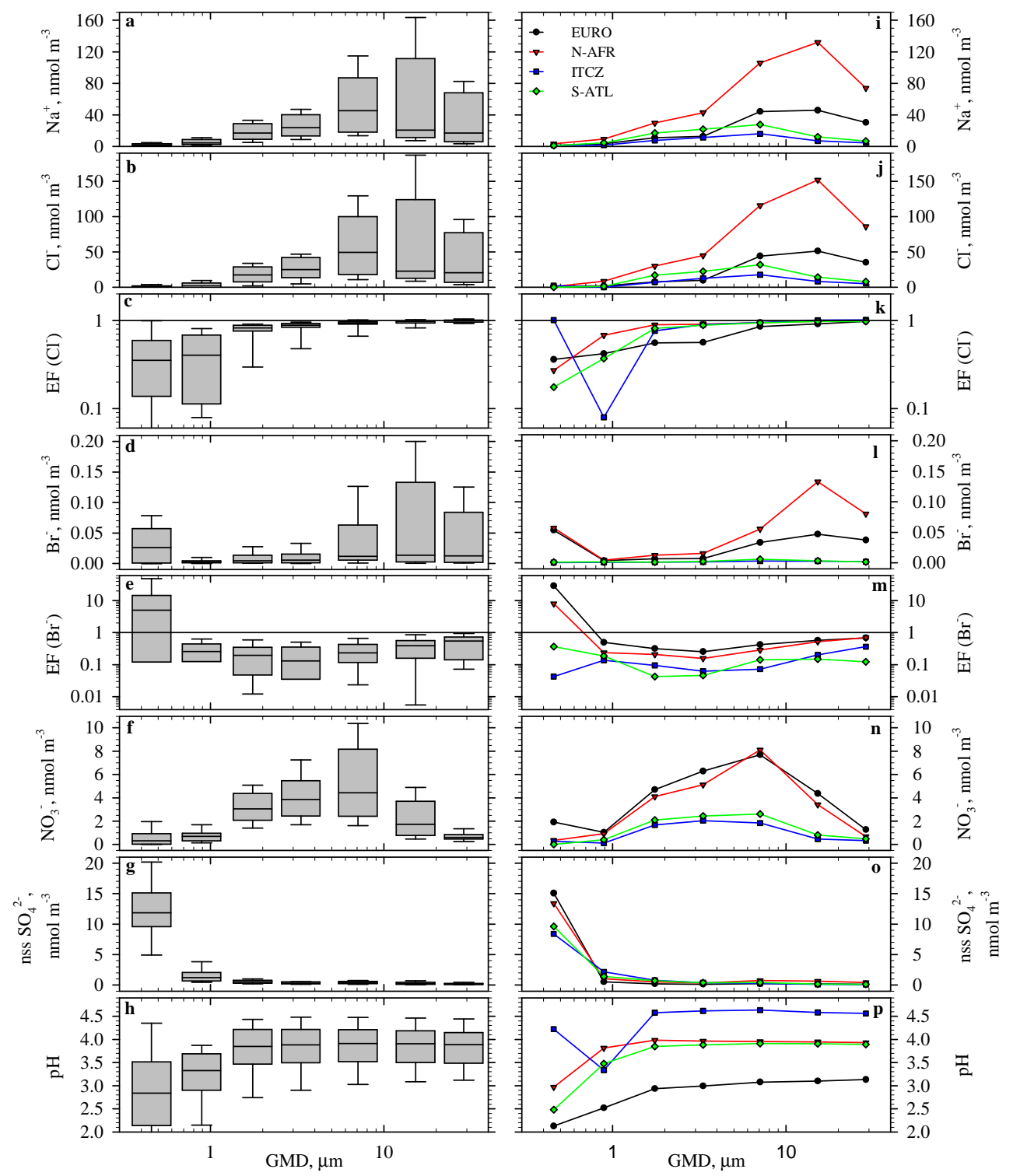

Fig. 3. Left: Box and whisker plots depicting measured and directly calculated particle size distributions (90th, 75th, 50th, 25th, and 10th percentiles) based on all data for (a) $\mathrm{Na}+,(\mathbf{b}) \mathrm{Cl}^{-}$, (c) $\mathrm{EF}(\mathrm{Cl}-),(\mathbf{d}) \mathrm{Br}^{-}$, (e) $\mathrm{EF}\left(\mathrm{Br}^{-}\right),(\mathbf{f}) \mathrm{NO}_{3}^{-}$, (g) nss $\mathrm{SO}_{4}^{2-}$, and (h) aerosol $\mathrm{pH}_{\text {inferred }}$ from the measured $\mathrm{HCl}$ phase partitioning. Right: Corresponding median size distributions of (i) $\left.\mathrm{Na}^{+},(\mathbf{j}) \mathrm{Cl}^{-},(\mathbf{k}) \mathrm{EF}^{-} \mathrm{Cl}^{-}\right),(\mathbf{l}) \mathrm{Br}^{-},(\mathbf{m})$ $\mathrm{EF}\left(\mathrm{Br}^{-}\right),(\mathbf{n}) \mathrm{NO}_{3}^{-},(\mathbf{o}) \mathrm{nss} \mathrm{SO}_{4}^{2-}$, and (p) aerosol $\mathrm{pH}$ for each transport regime.

concentrations within this regime varied by a factor of 10 (Fig. 2b) in response to the combined influences of variable wind velocity (Fig. 2a), sea state, and fetch (Fig. 1). The acidification of sea-salt aerosol and associated displacement of $\mathrm{HCl}$ resulted in the highest $\mathrm{HCl}$ mixing ratios (Figs. 2c, 4a, Table 3), lowest $\mathrm{EF}\left(\mathrm{Cl}^{-}\right)$s (Fig. 2b, Table 3), and lowest aerosol pHs inferred from measurements (Figs. 2g, 3p) during the cruise. $\mathrm{HCl}$ concentrations were generally greater than the corresponding deficits relative to sea salt (Fig. 2c), which assuming that sea-salt $\mathrm{Cl}^{-}$was the primary precursor for $\mathrm{HCl}$ (addressed below), indicates that $\mathrm{HCl}$ had longer atmospheric lifetimes against deposition than the parent aerosol. All size fractions were significantly dechlorinated; median $\mathrm{EF}\left(\mathrm{Cl}^{-}\right)$decreased with decreasing size (Fig. 3k).

Median size distributions of $\mathrm{Na}^{+}, \mathrm{NO}_{3}^{-}$, $\mathrm{nss}^{2-}$, and pH (Fig. 3i, n, o, and p, respectively), indicate that $\mathrm{HNO}_{3}$ partitioned preferentially with the less-acidic, super- $\mu \mathrm{m}-$ diameter, sea-salt size fractions and was the primary source of acidity incorporated into those size fractions. This is consistent with expectations based on both the $\mathrm{pH}$-dependence of its phase partitioning (e.g., Keene et al., 2004) and previously reported aerosol size distributions in near-surface air 
Table 3. Median values and ranges (in parentheses) for measured characteristics in each regime.

\begin{tabular}{llcccc}
\hline Analyte & Units & \multicolumn{1}{c}{ EURO } & N-AFR & ITCZ & S-ATL \\
\hline $\mathrm{HCl}$ & $\mathrm{pmol} \mathrm{mol}^{-1}$ & $682(106-1404)$ & $348(91-746)$ & $82(<23-207)$ & $267(81-453)$ \\
$\mathrm{Cl}$ & $\mathrm{pmol} \mathrm{mol}^{-1}$ & $27(<24-213)$ & $<24(<24-129)$ & $<24(<24-136)$ & $<24(<24-67)$ \\
$\mathrm{Br}_{t}$ & pmol mol $^{-1}$ & $7.2(3.1-12.3)$ & $18.8(8.2-30.1)$ & $2.4(<0.1-3.1)$ & $6.2(4.4-10.1)$ \\
$\mathrm{HNO}_{3}$ & pmol mol $^{-1}$ & $210(17-532)$ & $19(5-40)$ & $12(6-40)$ & $21(8-101)$ \\
$\mathrm{SO}_{2}$ & pmol mol $^{-1}$ & $289(238-2276)$ & $104(28-930)$ & $19(<1-48)$ & $23(5-77)$ \\
$\mathrm{O}_{3}$ & $\mathrm{nmol} \mathrm{mol}^{-1}$ & $35(5.4-47)$ & $38(20-45)$ & $22(12-35)$ & $23(14-35)$ \\
$\mathrm{Na}^{+a}$ & $\mathrm{nmol} \mathrm{m}^{-3}$ & $221(67-548)$ & $413(232-779)$ & $69(36-97)$ & $111(60-205)$ \\
$\mathrm{Cl}^{-b}$ & $\mathrm{nmol} \mathrm{m}^{-3}$ & $156(42-395)$ & $404(180-703)$ & $62(30-77)$ & $91(49-197)$ \\
$\left.\mathrm{EF}^{-} \mathrm{Cl}^{-}\right)^{\mathrm{b}}$ & & $0.86(0.63-0.97)$ & $0.94(0.89-0.96)$ & $0.90(0.88-0.99)$ & $0.87(0.77-0.93)$ \\
$\mathrm{Br}^{-a}$ & $\mathrm{nmol} \mathrm{m}^{-3}$ & $0.15(0.06-0.70)$ & $0.20(0.09-0.92)$ & $0.05(0.02-0.05)$ & $0.02(<0.01-0.10)$ \\
$\left.\mathrm{EF}^{-3} \mathrm{Br}^{-}\right)^{\mathrm{a}}$ & & $0.51(0.37-0.71)$ & $0.25(0.13-0.55)$ & $0.31(0.28-0.55)$ & $0.14(<0.01-0.33)$ \\
$\mathrm{NO}_{3}^{-b}$ & $\mathrm{nmol} \mathrm{m}^{-3}$ & $30.0(20.8-37.3)$ & $22.5(14.2-29.9)$ & $6.6(3.9-9.5)$ & $8.9(5.7-16.8)$ \\
$\mathrm{nss} \mathrm{SO}_{4}^{2-a}$ & $\mathrm{nmol} \mathrm{m}^{-3}$ & $15.1(10.3-39.2)$ & $15.3(9.2-20.3)$ & $15.3(8.2-22.0)$ & $16.6(7.8-25.6)$ \\
\hline
\end{tabular}

${ }^{a}$ Based on aerosol sampled in bulk. ${ }^{\mathrm{b}}$ Based on summed concentrations for aerosol size fractions sampled with cascade impactor.
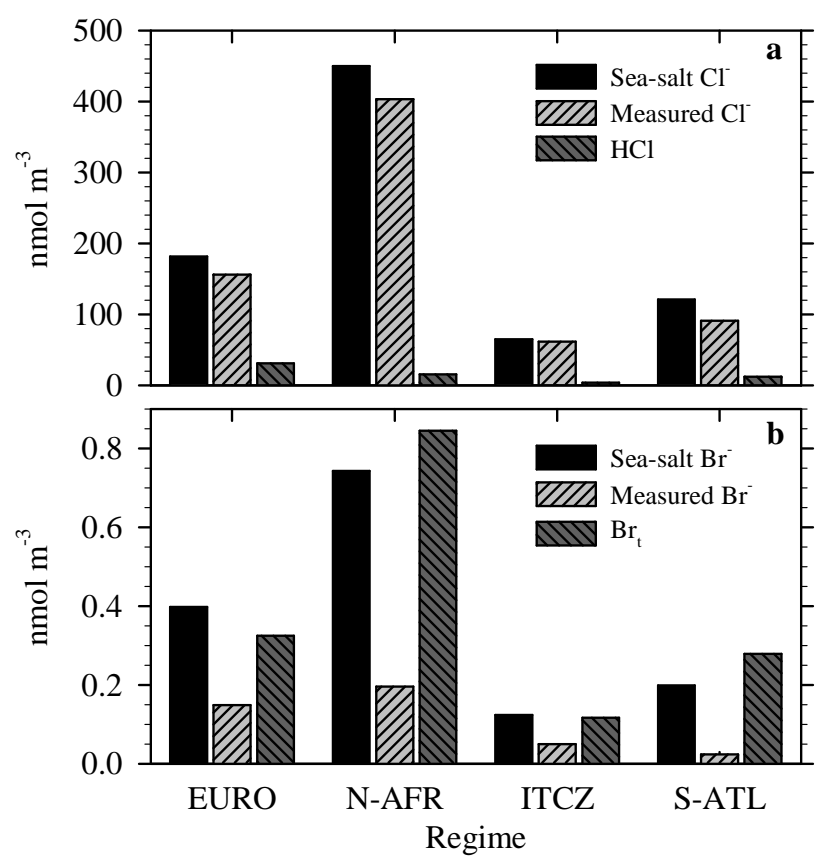

Fig. 4. Median measured concentrations of (a) $\mathrm{ss}^{-}$, measured $\mathrm{Cl}^{-}$, and $\mathrm{HCl}$, (b) ss $\mathrm{Br}^{-}$, measured $\mathrm{Br}^{-}$, and $\mathrm{Br}_{t}$ for each regime.

over the eastern North Atlantic Ocean (e.g., Huebert et al., 1996) and elsewhere. Low concentrations of nss $\mathrm{SO}_{4}^{2-}$ compared to $\mathrm{NO}_{3}^{-}$in super- $\mu \mathrm{m}$ size fractions (Fig. 3n, o) indicate that $\mathrm{H}_{2} \mathrm{SO}_{4}$ was a relatively minor source of acidity for super- $\mu \mathrm{m}$ marine aerosols. Due in part to the rapid turnover of super- $\mu \mathrm{m}$ aerosol and associated $\mathrm{NO}_{3}^{-}$, the median drydeposition flux of total $\mathrm{NO}_{3}$ was approximately four times greater than that of total nss $\mathrm{S}$ (Fig. 5).

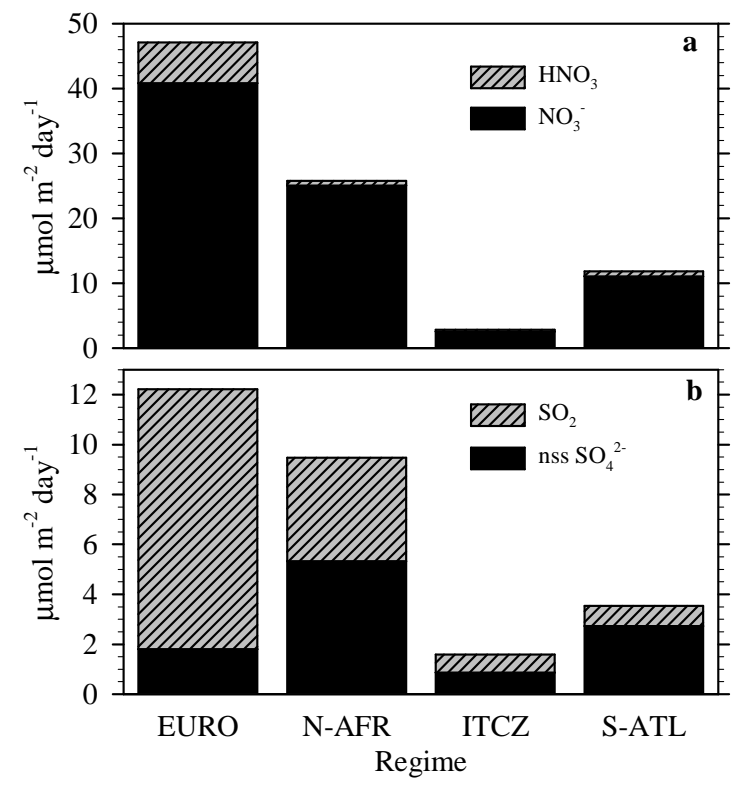

Fig. 5. Median dry-deposition fluxes of (a) $\mathrm{HNO}_{3}$ and particulate $\mathrm{NO}_{3}^{-}$, and (b) $\mathrm{SO}_{2}$ and particulate nss $\mathrm{SO}_{4}^{2-}$ for each regime calculated from measurements as described in Sect. 2.4.

$\mathrm{Cl}^{*}$ was generally less than $50 \mathrm{pmol} \mathrm{mol}^{-1}$ but higher mixing ratios (peaks between 100 and $213 \mathrm{pmol} \mathrm{mol}^{-1}$ ) were observed during three intervals, two within several hours after sunrise and the other within several hours after sunset (Fig. 2c). However, systematic diel variability was not evident, which is consistent with past observations and model calculations (Pszenny et al., 2004; Keene et al., 2007a; Pechtl and von Glasow, 2007). The first two intervals of high $\mathrm{Cl}^{*}$ occurred in parallel with relatively high $\mathrm{RHs}(65.6 \%$ to $68.5 \%$, Fig. 2a) suggesting a possible link between aerosol water content and net $\mathrm{Cl}^{*}$ production. 
Bulk aerosol was significantly depleted in $\mathrm{Br}^{-}$relative to seawater (Fig. 2b, Table 3) but the smallest size fraction was highly enriched (Fig. 31, m). The enrichment of $\mathrm{Br}^{-}$in sub$\mu \mathrm{m}$ aerosol in marine regions has been widely reported (e.g., Sander et al., 2003) but the major cause is not understood. Nascent marine aerosols are not enriched in $\mathrm{Br}$ when initially injected into the atmosphere from the ocean surface (Keene et al., 2007b) and, as detailed below, model calculations based on the halogen activation mechanism (e.g., Vogt et al., 1996) do not predict the significant retention of $\mathrm{Br}^{-}$ in sea-salt aerosol or the accumulation of $\mathrm{Br}^{-}$in sub- $\mu \mathrm{m}$ aerosol size fractions. These results suggest the possibility that significant concentrations of $\mathrm{Br}$ associated with marine aerosol in the EURO region (and elsewhere) may be present as relatively unreactive, perhaps organic compounds that either originate from non-marine sources or are produced by chemical pathways not considered in current models. However, the median estimated emission fluxes of sea-salt $\mathrm{Br}^{-}$ (and $\mathrm{Cl}^{-}$) were approximately balanced by the corresponding dry-deposition fluxes of total $\mathrm{Br}\left(\mathrm{Br}_{t}\right.$ and particulate $\left.\mathrm{Br}^{-}\right)$ (and total $\mathrm{Cl}, \mathrm{HCl}+$ particulate $\mathrm{Cl}^{-}$, Fig. 6), which suggests that the production of sea salt was the primary source for inorganic $\mathrm{Br}$ and $\mathrm{Cl}$ in this regime. Similar relationships were observed in polluted air along the northeastern US coast (Keene et al., 2007a). In addition, available evidence indicates that the analytical technique used here (ion chromatography) is specific for $\mathrm{Br}^{-}$and it is unlikely that simple dilution during extraction or exposure to eluent solutions or separator column resins would convert bromine sequestered in the chemical lattice of relatively inert compounds to $\mathrm{Br}^{-}$. Regardless of speciation, the net effect of retaining and/or accumulating significant marine-derived $\mathrm{Br}^{-}$in the particulate phase would be to slow production rates of Br-radical precursors and to modify the importance of different pathways in the cycle relative to those predicated by current models. For example, as $\mathrm{EF}\left(\mathrm{Br}^{-}\right)$decreases, the importance of $\mathrm{HOBr}+\mathrm{Cl}^{-}+\mathrm{H}^{+} \rightarrow \mathrm{BrCl}+\mathrm{H}_{2} \mathrm{O}$ and subsequent transformations increases relative to $\mathrm{HOBr}+\mathrm{Br}^{-}+\mathrm{H}^{+} \rightarrow \mathrm{Br}_{2}+\mathrm{H}_{2} \mathrm{O}$ (e.g., Vogt et al., 1996; Fickert et al., 1999). Consequently, the nature of this characteristic of the system must be resolved in order to develop a reliable predictive capability for Br-radical chemistry and the associated influences on the evolution of marine air.

$\mathrm{Br}_{t}$ was present at higher concentrations than the corresponding particulate- $\mathrm{Br}^{-}$deficit relative to sea salt (Figs. 2d, $7 \mathrm{~b}$ ), which assuming that sea salt was the primary source for total $\mathrm{Br}$, indicates that $\mathrm{Br}_{t}$ had a longer atmospheric lifetime than the parent aerosol. In addition, $\mathrm{Br}_{t}$ varied systematically over diel cycles with daytime mixing ratios approximately two times greater than those at night (Fig. 2d). In contrast, the corresponding $\mathrm{Br}^{-}$deficits in bulk aerosol exhibited relatively less day-night variability (Fig. 2d).

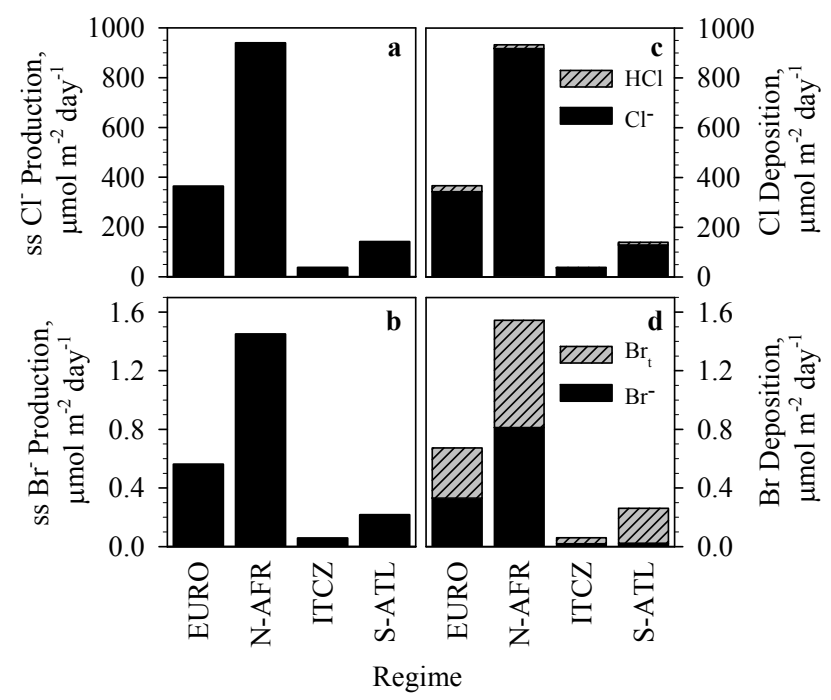

Fig. 6. Median emission fluxes of (a) sea-salt $\mathrm{Cl}^{-}$and (b) sea-salt $\mathrm{Br}^{-}$inferred from dry-deposition fluxes of particulate $\mathrm{Na}^{+}$versus median dry-deposition fluxes of (c) $\mathrm{HCl}$ and particulate $\mathrm{Cl}^{-}$, and (d) $\mathrm{Br}_{t}$ and particulate $\mathrm{Br}^{-}$for each regime calculated from measurements as described in Sect. 2.4.

\subsubsection{Simulated characteristics}

The simulated steady-state mixing ratios of $\mathrm{NO}_{\mathrm{x}}$ in the EURO regime for the "with halogens" run averaged $171 \mathrm{pmol} \mathrm{mol}^{-1}$ over diel cycles (Fig. 8, Table 4). The corresponding simulated $\mathrm{NO}_{2}\left(163 \mathrm{pmol} \mathrm{mol}^{-1}\right)$ was within the broad range of daily averages for $\mathrm{NO}_{2}$ measured in this region by Leser et al. (2003) ( 20 to $\left.1160 \mathrm{pmol} \mathrm{mol}^{-1}\right)$. Simulated size distributions of particulate $\mathrm{NO}_{3}^{-}, \mathrm{nss}_{4}^{2-}$, and $\mathrm{Cl}^{-}$for the "with halogen" run (Fig. 9) were similar to those based on median values for the measured near-surface concentrations (Fig. 3n, o, j, respectively). The simulated mixing ratios of $\mathrm{HNO}_{3}$ (495 to $575 \mathrm{pmol} \mathrm{mol}^{-1}$, not shown) overlapped the upper limit for mixing ratios measured within this regime (Fig. 2e, Table 3). Simulated $\mathrm{SO}_{2}$ (456 to $501 \mathrm{pmol} \mathrm{mol}^{-1}$, not shown) fell within the upper range of observations (Fig. 2f, Table 3) and simulated $\mathrm{HCl}$ (Fig. 8, 251 to $293 \mathrm{pmol} \mathrm{mol}^{-1}$ ) was less than most observations (Fig. 2c, Table 3). The differences between simulated and observed $\mathrm{HNO}_{3}$ and $\mathrm{HCl}$ both in this and other regimes resulted in part from the scaling approach employed to parameterize average aerosol concentrations and turnover rates for the simulations. The relatively lower $\mathrm{HNO}_{3}$ and higher $\mathrm{HCl}$ measured in nearsurface air reflect local phase partitioning with the greater near-surface aerosol volumes whereas the simulated results correspond to column-averaged conditions.

Simulated $\mathrm{pHs}$ for size fractions other than the largest and smallest in the "with halogens" run (Fig. 8, 2.5 to 2.9) were consistent with median values calculated directly from the measured phase partitioning of $\mathrm{HCl}$ (Fig. 3p, 2.5 to 3.1). Similar factors contribute to deviations between simulated 
Table 4. Simulated characteristics of each flow regime.

\begin{tabular}{|c|c|c|c|c|}
\hline & EURO $^{\mathrm{a}}$ & N-AFR ${ }^{a}$ & $\mathrm{ITCZ}^{\mathrm{a}}$ & S-ATL ${ }^{\mathrm{a}}$ \\
\hline $\mathrm{Cl}^{*}$ (24-h mean), $\mathrm{pmol} \mathrm{mol}^{-1}$ & 78 & 19 & 26 & 14 \\
\hline $\mathrm{HOCl}$ (daytime max.), $\mathrm{pmol} \mathrm{mol}^{-1}$ & 51 & 11 & 21 & 8.8 \\
\hline $\mathrm{ClNO}_{3}$ (daytime max.), $\mathrm{pmol} \mathrm{mol}^{-1}$ & 21 & 1.8 & 2.2 & 0.9 \\
\hline $\mathrm{Cl}_{2}$ (nighttime, max.), $\mathrm{pmol} \mathrm{mol}^{-1}$ & 36 & 2.8 & 5.3 & 2.0 \\
\hline $\mathrm{BrCl}$ (nighttime, max.), mol mol$^{-1}$ & 15 & 16 & 7.0 & 10 \\
\hline $\mathrm{ClNO}_{2}$ (nighttime, $\max$ ), $\mathrm{pmol} \mathrm{mol}^{-1}$ & 4.6 & 0.06 & 0.01 & 0.01 \\
\hline $\mathrm{Cl}$-atom conc. (daytime max.) $\mathrm{cm}^{-3}$ & $4.3 \times 10^{4}$ & $7.8 \times 10^{4}$ & $2.1 \times 10^{4}$ & $4.1 \times 10^{4}$ \\
\hline \multicolumn{5}{|l|}{ Primary Sources for atomic $\mathrm{Cl}^{\mathrm{b}}$} \\
\hline $\mathrm{ClO}+\mathrm{NO}, \%$ & 36 & 24 & 16 & 22 \\
\hline $\mathrm{BrCl}$ photolysis, \% & 25 & 66 & 62 & 64 \\
\hline $\mathrm{Cl}_{2}$ photolysis, $\%$ & 24 & 3 & 7 & 1 \\
\hline $\mathrm{HOCl}$ photolysis, \% & 12 & 6 & 15 & 11 \\
\hline $\mathrm{ClNO}_{2}$ photolysis, $\%$ & 0.4 & 0.01 & $<0.01$ & $<0.01$ \\
\hline $\mathrm{Br}_{t}(24-\mathrm{h}$ mean $), \mathrm{pmol} \mathrm{mol}^{-1}$ & 15 & 37 & 8.3 & 23 \\
\hline $\mathrm{BrNO}_{3}$ (daytime max.), $\mathrm{pmol} \mathrm{mol}^{-1}$ & 14 & 18 & 3.2 & 9.5 \\
\hline $\mathrm{HOBr}$ (daytime max.), $\mathrm{pmol} \mathrm{mol}^{-1}$ & 2.5 & 11 & 3.2 & 7.4 \\
\hline $\mathrm{HBr}$ (daytime max.), pmol mol-1 & 1.6 & 18 & 1.2 & 12 \\
\hline $\mathrm{BrO}$ (daytime max.), pmol mol-1 & 1.0 & 7.8 & 3.0 & 6.5 \\
\hline $\mathrm{BrCl}$ (nighttime max.), $\mathrm{pmol} \mathrm{mol}^{-1}$ & 15 & 16 & 7.0 & 10 \\
\hline $\mathrm{Br}_{2}$ (nightime max.), pmol mol-1 & 1.0 & 13 & 0.7 & 6.9 \\
\hline \multicolumn{5}{|l|}{ Primary Sources for atomic $\mathrm{Br}^{\mathrm{b}}$} \\
\hline $\mathrm{BrO}+\mathrm{NO}, \%$ & 50 & 31 & 15 & 26 \\
\hline $\mathrm{BrCl}$ photolysis, \% & 26 & 18 & 38 & 19 \\
\hline $\mathrm{HOBr}$ photolysis, \% & 10 & 19 & 24 & 29 \\
\hline $\mathrm{Br}_{2}$ photolysis, $\%$ & $<1$ & 21 & 7 & 16 \\
\hline $\mathrm{NO}_{\mathrm{x}}(24-\mathrm{h}$ mean $), \mathrm{pmol} \mathrm{mol}^{-1}$ & 171 & 31 & 8.3 & 20 \\
\hline $\mathrm{NO}_{\mathrm{x}}$ (24-h mean, "no halogens"), $\mathrm{pmol} \mathrm{mol}^{-1}$ & 237 & 62 & 27 & 37 \\
\hline $\mathrm{NO}$ (daytime max.), pmol mol ${ }^{-1}$ & 28 & 10 & 1.7 & 7.6 \\
\hline $\mathrm{NO}$ (daytime max., "no halogens"), $\mathrm{pmol} \mathrm{mol}^{-1}$ & 42 & 16 & 6.0 & 12 \\
\hline \multicolumn{5}{|l|}{ Primary Heterogeneous sinks for $\mathrm{NO}_{\mathrm{x}}^{\mathrm{b}}$} \\
\hline $\mathrm{S}$ aerosol, \% heterogeneous ${ }^{\mathrm{c}}$ & 91 & 69 & 86 & 79 \\
\hline $\mathrm{ClNO}_{3}$ hydrolysis, \% heterogeneous ${ }^{\mathrm{d}}$ & 53 & 14 & 54 & 16 \\
\hline $\mathrm{BrNO}_{3}$ hydrolysis, \% heterogeneous ${ }^{\mathrm{d}}$ & 27 & 54 & 33 & 59 \\
\hline $\mathrm{N}_{2} \mathrm{O}_{5}$ hydrolysis, \% heterogeneous ${ }^{\mathrm{d}}$ & 11 & $<1$ & $<1$ & $<1$ \\
\hline $\mathrm{BrNO}_{3}+\mathrm{Cl}^{-}, \%$ heterogeneous ${ }^{\mathrm{d}}$ & 3 & 19 & 3 & 12 \\
\hline $\mathrm{OH}$ (daytime max.), $\mathrm{pmol} \mathrm{mol}^{-1}$ & 0.11 & 0.10 & 0.022 & 0.15 \\
\hline $\mathrm{OH}$ (daytime max., "no halogens"), $\mathrm{pmol} \mathrm{mol}^{-1}$ & 0.13 & 0.22 & 0.031 & 0.25 \\
\hline \multicolumn{5}{|l|}{ Primary sources for $\mathrm{OH}^{\mathrm{b}}$} \\
\hline $\mathrm{HO}_{2}+\mathrm{NO}, \%$ & 58 & 36 & 9 & 34 \\
\hline $\mathrm{HO}_{2}+\mathrm{O}_{3}, \%$ & 29 & 13 & 41 & 16 \\
\hline $\mathrm{HOBr}+h v, \%$ & 4 & 35 & 27 & 29 \\
\hline \multicolumn{5}{|l|}{ Primary sinks for $\mathrm{OH}^{\mathrm{b}}$} \\
\hline $\mathrm{OH}+\mathrm{CO}, \%$ & 31 & 39 & 47 & 31 \\
\hline $\mathrm{OH}+\mathrm{CH}_{4}+\mathrm{O}_{2}, \%$ & 23 & 24 & 20 & 25 \\
\hline $\mathrm{OH}+\mathrm{H}_{2}, \%$ & 13 & 14 & 12 & 15 \\
\hline $\mathrm{HO}_{2}$ (daytime max.), $\mathrm{pmol} \mathrm{mol}^{-1}$ & 9.2 & 12 & 4.4 & 14 \\
\hline $\mathrm{HO}_{2}$ (daytime max., "no halogens"), $\mathrm{pmol} \mathrm{mol}^{-1}$ & 8.2 & 17 & 6.0 & 18 \\
\hline \multicolumn{5}{|l|}{ Primary sources for $\mathrm{HO}_{2}^{\mathrm{b}}$} \\
\hline $\mathrm{H}+\mathrm{O}_{2}+\{\mathrm{M}\}, \%$ & 46 & 56 & 61 & 56 \\
\hline $\mathrm{NO}+\mathrm{CH}_{3} \mathrm{O}_{2}, \%$ & 25 & 18 & 9 & 16 \\
\hline \multicolumn{5}{|l|}{ Primary sinks for $\mathrm{HO}_{2}^{\mathrm{b}}$} \\
\hline $\mathrm{HO}_{2}+\mathrm{NO}, \%$ & 47 & 22 & 6 & 19 \\
\hline $\mathrm{HO}_{2}+\mathrm{O}_{3}, \%$ & 24 & 8 & 27 & 9 \\
\hline $\mathrm{HO}_{2}+\mathrm{HO}_{2}, \%$ & 9 & 16 & 8 & 23 \\
\hline $\mathrm{HO}_{2}+\mathrm{BrO}, \%$ & 6 & 35 & 32 & 23 \\
\hline $\mathrm{HO}_{2}+\mathrm{CH}_{3} \mathrm{O}_{2}, \%$ & 6 & 13 & 16 & 21 \\
\hline $\mathrm{O}_{3}(24-\mathrm{h}$ mean $), \mathrm{nmol} \mathrm{mol}^{-1}$ & 49 & 14 & 29 & 14 \\
\hline $\mathrm{O}_{3}$ (24-h mean, "no halogen"), $\mathrm{nmol} \mathrm{mol}^{-1}$ & 64 & 37 & 41 & 28 \\
\hline \multicolumn{5}{|l|}{ Primary chemical sinks for $\mathrm{O}_{3}^{\mathrm{b}}$} \\
\hline $\mathrm{O}_{3}+\mathrm{NO}, \%$ & 66 & 15 & 11 & 11 \\
\hline $\mathrm{O}_{3}+h v, \%$ & 20 & 35 & 45 & 55 \\
\hline $\mathrm{O}_{3}+\mathrm{Br}, \%$ & 5 & 46 & 35 & 30 \\
\hline $\mathrm{O}_{3}+\mathrm{Cl}, \%$ & 3 & 2 & 5 & 1 \\
\hline \multicolumn{5}{|l|}{ Primary sources for particulate nss $\mathrm{SO}_{4}^{2-b}$} \\
\hline $\mathrm{H}_{2} \mathrm{SO}_{4}$ scavenging, $\%$ & 96 & 81 & 50 & 92 \\
\hline $\mathrm{HOCl}+\mathrm{S}(\mathrm{IV}), \%$ & 3 & 11 & 39 & 3 \\
\hline
\end{tabular}

${ }^{a}$ Unless otherwise noted, results correspond to "with halogens" runs. ${ }^{\mathrm{b}}$ Integrated over $24 \mathrm{~h} .{ }^{\mathrm{c}}$ Percentage of total heterogeneous $\mathrm{NO}_{\mathrm{x}}$ sink that involves reactions on S-aerosol surfaces; the balance involves reactions on sea-salt-aerosol surfaces. ${ }^{\mathrm{d}}$ Percentage contribution to total heterogeneous $\mathrm{NO}_{\mathrm{X}}$ sink involving both sea-salt and $\mathrm{S}$ aerosol. 

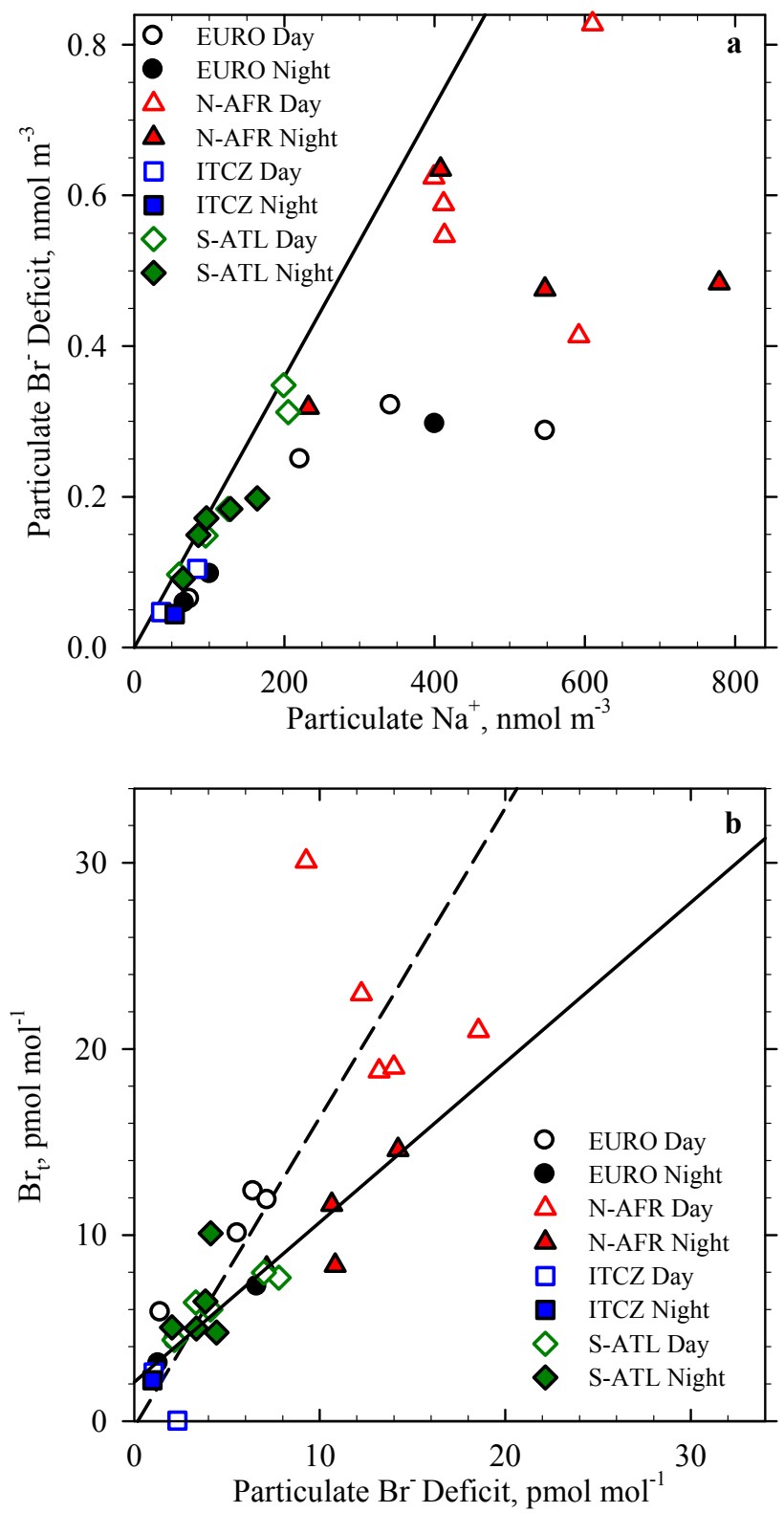

Fig. 7. (a) Measured absolute particulate $\mathrm{Br}^{-}$deficit relative to sea salt versus particulate $\mathrm{Na}^{+}$within the four regimes. The line depicts the ratio of particulate $\mathrm{Br}^{-}$to $\mathrm{Na}^{+}$in seawater $\left(0.001798 \mathrm{~mol} \mathrm{~mol}^{-1}\right)$. (b) Measured $\mathrm{Br}_{t}$ versus absolute particulate $\mathrm{Br}^{-}$deficit relative to sea salt within the four regimes. Lines depict reduced major axis regressions (Keene et al., 1986) for daytime (dashed, slope $=1.66, \mathrm{Y}$ intercept $=-0.3$, and $\left.r^{2}=0.64\right)$ and nighttime (solid, slope $=0.88, \mathrm{Y}$ intercept $=2.1$, and $r^{2}=0.77$ ) .

and calculated $\mathrm{pHs}$ for largest and smallest size fractions in this and other regimes. The relatively higher simulated $\mathrm{pH}$ for the largest size fraction reflects the rapid turnover rates of large aerosols relative to the kinetics of phase change. Freshly produced and aged aerosols were not simulated as external mixtures. The instantaneous mixing of fresh with chemically aged aerosols during each time step sustained substantial undersaturation of the largest size fraction with respect to acidic gases and, thus, higher solution $\mathrm{pH}$ relative to smaller super- $\mu \mathrm{m}$ size fractions (e.g., Pszenny et al., 2004). In contrast, pHs inferred from the measured phase partitioning of $\mathrm{HCl}$ were based on the assumption of thermodynamic equilibrium and, consequently, inferred $\mathrm{pHs}$ for the larger, undersaturated size fractions represent lower limits (Keene et al., 2004). $\mathrm{Cl}^{-}$concentrations associated with the smallest aerosol size fraction in the EURO regime (median of $0.8 \mathrm{nmol} \mathrm{m}^{-3}$; Fig. 3j) were near the average detection limit $\left(1.0 \mathrm{nmol} \mathrm{m}^{-3}\right)$, which contributed to large uncertainties in estimating $\mathrm{pHs}$ for this size fraction based on $\mathrm{HCl}$ partitioning. In addition, as described below, the model failed to reproduce some features of sub- $\mu \mathrm{m}$ aerosol composition suggesting that it may be missing some important processes. Both factors may contribute to the relatively large differences between inferred versus simulated $\mathrm{pHs}$ for the smaller size fractions.

The higher simulated pHs (and associated differences in the phase partitioning of $\mathrm{HNO}_{3}$ ) in the "with halogens" relative to the "no halogens" runs for this and other regimes (Figs. 8 and 9) reflect the influences of $\mathrm{HCl}$ phase partitioning on aerosol solution acidity in the former versus lack thereof in the latter. Acid displacement of $\mathrm{HCl}$ by more soluble acids (primarily $\mathrm{HNO}_{3}$ ) transfers acidity from the aerosol solution to the gas phase thereby sustaining relatively higher solution $\mathrm{pH}$ in the "with halogens" run (e.g., Keene et al., 1998).

Simulated $\mathrm{Cl}^{*}$ (defined here as the sum of volatile inorganic $\mathrm{Cl}$ species other than $\mathrm{HCl}$ ) varied from 52 to $100 \mathrm{pmol} \mathrm{mol}^{-1}$ over diel cycles (Fig. 8). Although the $\mathrm{Cl}^{*}$ measurements did not indicate systematic diel variability, the simulated values were within the range of observations (Fig., 2c, Table 3). In the model, $\mathrm{Cl}^{*}$ was dominated during the daytime by $\mathrm{HOCl}$ and $\mathrm{ClNO}_{3}$ and at night by $\mathrm{Cl}_{2}$ and $\mathrm{BrCl}$ (Fig. 8, Table 4). In close proximity to large urban and industrial emission sources for $\mathrm{NO}_{\mathrm{x}}, \mathrm{ClNO}_{2}$ produced via the nocturnal reaction $\mathrm{N}_{2} \mathrm{O}_{5}+\mathrm{Cl}^{-} \rightarrow \mathrm{ClNO}_{2}+\mathrm{NO}_{3}^{-}$may accumulate in the dark to mixing ratios $>1000 \mathrm{pmol} \mathrm{mol}^{-1}$ (Osthoff et al., 2008). However, $\mathrm{NO}_{\mathrm{x}}$ is efficiently oxidized to $\mathrm{HNO}_{3}$ and particulate $\mathrm{NO}_{3}^{-}$in marine air and deposited to the surface. Consequently, $\mathrm{NO}_{\mathrm{x}}$ mixing ratios (e.g., Neuman et al., 2006) and the associated nocturnal production of $\mathrm{ClNO}_{2}$ decrease rapidly over the ocean with distance from sources, consistent with the simulated values reported herein. For example, relative to the EURO runs in which depositional losses of oxidized $\mathrm{N}$ were replaced by an aged mixture of $\mathrm{HNO}_{3}$ and $\mathrm{NO}_{2}$ in a ratio of $1: 1$, a sensitivity run in which losses were replaced entirely by freshly emitted $\mathrm{NO}$ yielded steady-state $\mathrm{NO}_{\mathrm{x}}$ mixing ratios averaging $237 \mathrm{pmol} \mathrm{mol}^{-1}$ and a maximum $\mathrm{ClNO}_{2}$ mixing ratio of $19 \mathrm{pmol} \mathrm{mol}^{-1}$, which were factors of 2 and 4 higher, respectively. 


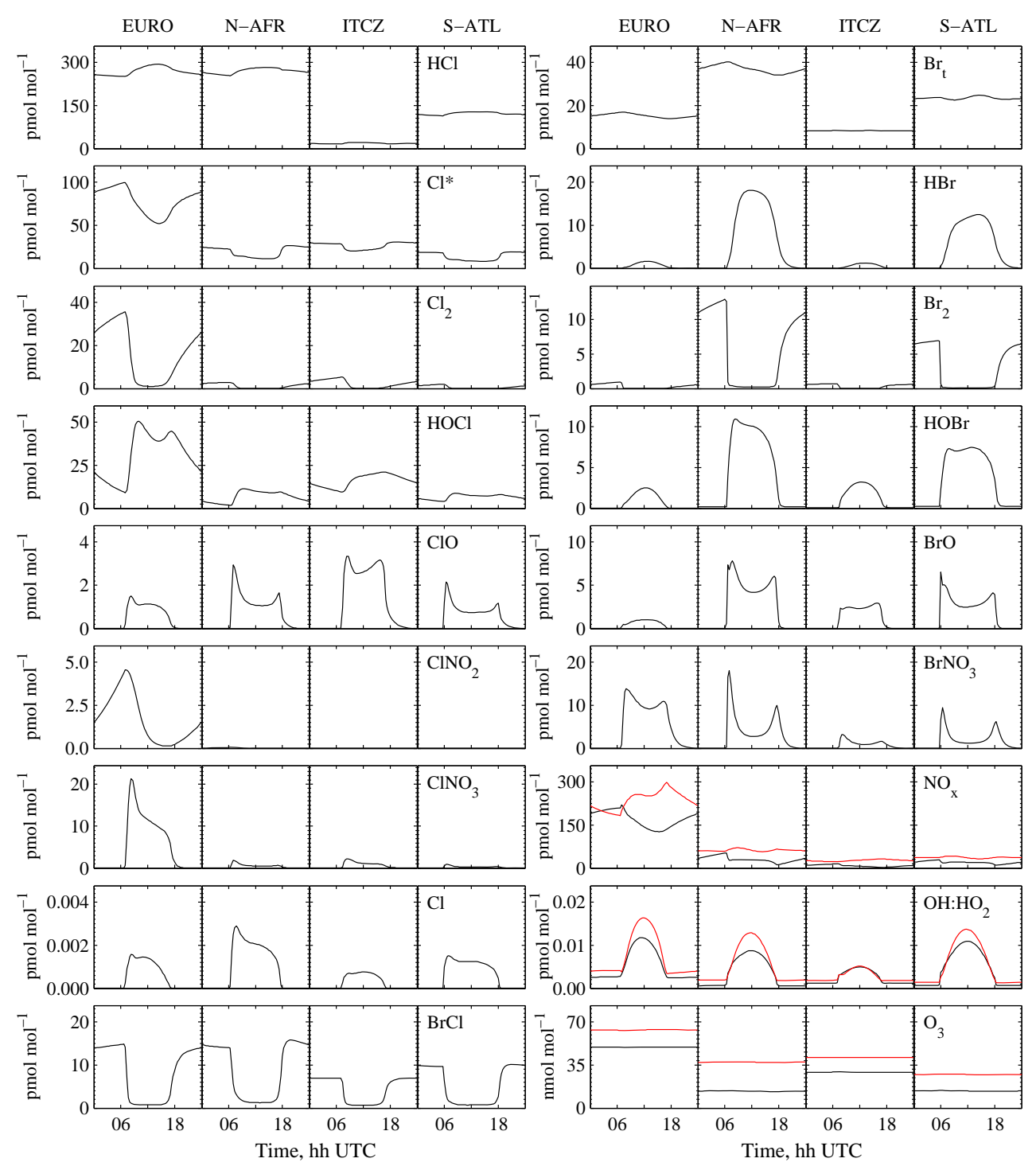

Fig. 8. Simulated diel cycles in mixing ratios of gas-phase species for the four flow regimes; values for runs "with halogens" are in black and those with "no halogens" are in red.

Integrated over $24 \mathrm{~h}, \mathrm{Cl}$-atom production was dominated by $\mathrm{ClO}+\mathrm{NO}$ and the photolysis of $\mathrm{BrCl}$ and $\mathrm{Cl} 2$ whereas $\mathrm{ClNO}_{2}$ accounted for only $0.4 \%$ of the total (Table 4 ) but the relative importance of different pathways varied over diel cycles. Following sunrise, the photolysis of $\mathrm{Cl}_{2}$ and $\mathrm{BrCl}$ (produced primarily via heterogeneous reactions of hypohalous acids and halide ions) dominated (49\% and 32\%, respectively). Photolysis of $\mathrm{ClNO}_{2}$ accounted for less than $1 \%$ of $\mathrm{Cl}$-atom production during this period. During midday, $\mathrm{ClO}+\mathrm{NO}$ was the most important single pathway (48\%) with photolysis of $\mathrm{HOCl}(19 \%), \mathrm{BrCl}(19 \%)$ and $\mathrm{Cl}_{2}(10 \%)$ accounting for most of the balance. Cl-atom concentrations peaked following sunrise at $4.3 \times 10^{4} \mathrm{~cm}^{-3}$, remained high through midday, and declined in the late afternoon (Fig. 8). Although the $\mathrm{Cl}$-atom production pathways under steady- state conditions in the EURO regime were not dominated by the autocatalytic recycling of $\mathrm{Cl}_{2}$ as simulated in aging pollution plumes elsewhere (Pechtl and von Glasow, 2007; Lawler et al., 2009), the absolute concentrations during daytime were similar. At these levels, oxidation by $\mathrm{Cl}$ would have been a significant sink for alkanes (e.g., Wingenter et al., 1996; Pszenny et al., 2007) and accounted for $24 \%$ of simulated $\mathrm{CH}_{4}$ oxidation within the EURO MBL.

Simulated concentrations of particulate $\mathrm{Br}^{-}$indicate that all size fractions except the largest were almost completely debrominated (Fig. 9). As discussed above, however, measured distributions reveal large enrichment in the finest size fraction and retention of significant $\mathrm{Br}^{-}$in the larger super- $\mu \mathrm{m}$ size fractions (Fig. 31, m). Causes for these differences are unknown. However, the retention and/or 


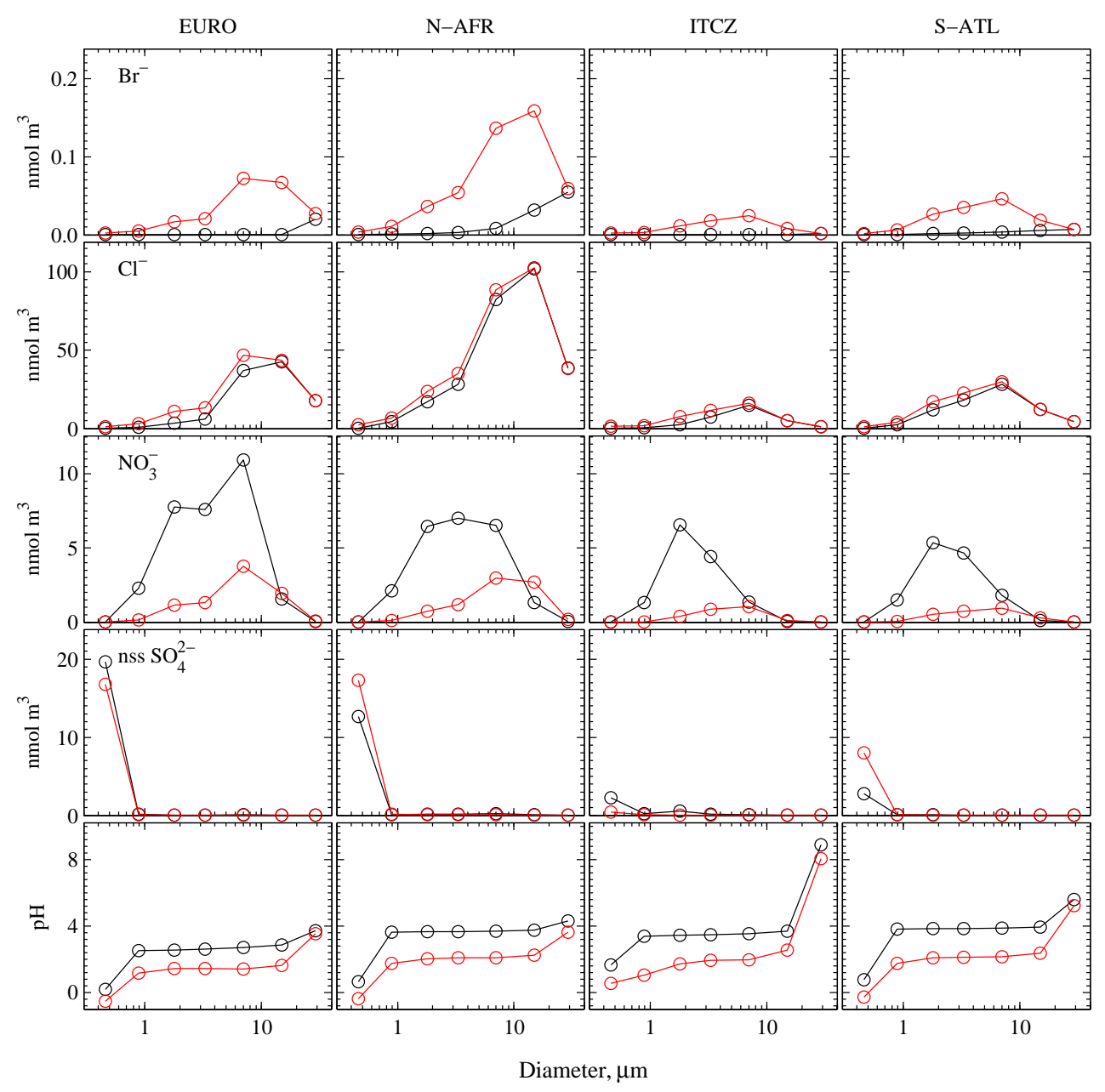

Fig. 9. Simulated average size distributions of particulate-phase species for the four flow regimes; values for runs "with halogens" are in black and those with "no halogens" are in red. To facilitate direct comparison with measured size distributions, constituents associated with the $\mathrm{S}$ size bin have been added to those associated with the smallest sea-salt size bin.

accumulation of significant $\mathrm{Br}^{-}$in the ambient aerosol (median $\left.\mathrm{EF}\left(\mathrm{Br}^{-}\right)=0.52\right)$ implies that volatile inorganic $\mathrm{Br}$ in the model is overestimated, which is consistent with the factor of two higher mixing ratios of simulated $\mathrm{Br}_{t}$ (daily average $=15 \mathrm{pmol} \mathrm{mol}^{-1}$, Fig. 8, Table 4) relative to measured $\mathrm{Br}_{t}$ (Fig. 2d, Table 3) in this regime. In addition, simulated $\mathrm{Br}_{t}$ exhibited little diel variability (Fig. 8) whereas that in measured $\mathrm{Br}_{t}$ was marked (Fig. 2d). Causes for these differences in diel behavior are not known. In the model, $\mathrm{Br}_{t}$ was dominated by $\mathrm{BrCl}$ at night and $\mathrm{BrNO}_{3}$ during the day (Fig. 8, Table 4). The primary sources for atomic $\mathrm{Br}$ were $\mathrm{BrO}+\mathrm{NO}$ and $\mathrm{BrCl}$ photolysis (Table 4).

Destruction of $\mathrm{O}_{3}$ by atomic $\mathrm{Br}\left(\mathrm{O}_{3}+\mathrm{Br} \rightarrow \mathrm{BrO}+\mathrm{O}_{2}\right)$ in the model accounted for $5 \%$ of the total $\mathrm{O}_{3}$ sink associated with all major chemical pathways (including photolysis and reaction with $\mathrm{NO}, \mathrm{NO}_{2}, \mathrm{OH}, \mathrm{HO}_{2}$, and atomic $\mathrm{Cl}$ ). Reaction with atomic $\mathrm{Cl}$ accounted for $3 \%$ of the total. Simulated mixing ratios of product $\mathrm{BrO}$ (maximum and midday averages of 1.0 and $0.83 \mathrm{pmol} \mathrm{mol}^{-1}$, respectively, Fig. 8), were consistent with measurements of $\mathrm{BrO}$ (upper limit of $\sim 1 \mathrm{pmol} \mathrm{mol}^{-1}$ ) in this region during a previous cruise of the Polarstern (Leser et al., 2003). At the high $\mathrm{NO}_{\mathrm{x}}$ mixing ratios in this regime, halogen radical recycling in the gas phase and associated $\mathrm{O}_{3}$ destruction was slowed by the formation of halogen nitrates (i.e., $\mathrm{BrO}+\mathrm{NO}_{2} \rightarrow \mathrm{BrNO}_{3}$ competed with $\mathrm{BrO}+\mathrm{HO}_{2} \rightarrow \mathrm{HOBr}$ ), which accumulated to significant concentrations (Fig. 8, Table 4.). Reactions involving $\mathrm{S}$ aerosol accounted for $91 \%$ of the total heterogenous $\mathrm{NO}_{\mathrm{x}}$ sinks (Fig. 10). Hydrolysis reactions involving $\mathrm{ClNO}_{3}$ and $\mathrm{BrNO}_{3}$ to produce hypohalous acids and hydrolysis of $\mathrm{N}_{2} \mathrm{O}_{5}$ to produce $\mathrm{HNO}_{3}$ were the most important of these pathways (Table 4). Of those involving sea salt, the reaction of $\mathrm{ClNO}_{3}(41 \%)$ and $\mathrm{BrNO}_{3}(26 \%)$ with $\mathrm{Cl}^{-}$to produce $\mathrm{Cl}_{2}$ and $\mathrm{BrCl}$, respectively, were most important. Comparisons between rates of $\mathrm{NO}_{\mathrm{x}}$ processing (Fig. 10) and corresponding differences in simulated $\mathrm{NO}_{\mathrm{x}}$ mixing ratios in the "with halogens" versus "no halogen" runs (averages of 171 and $237 \mathrm{pmol} \mathrm{mol}^{-1}$, respectively, Fig. 8, Table 4) indicates 

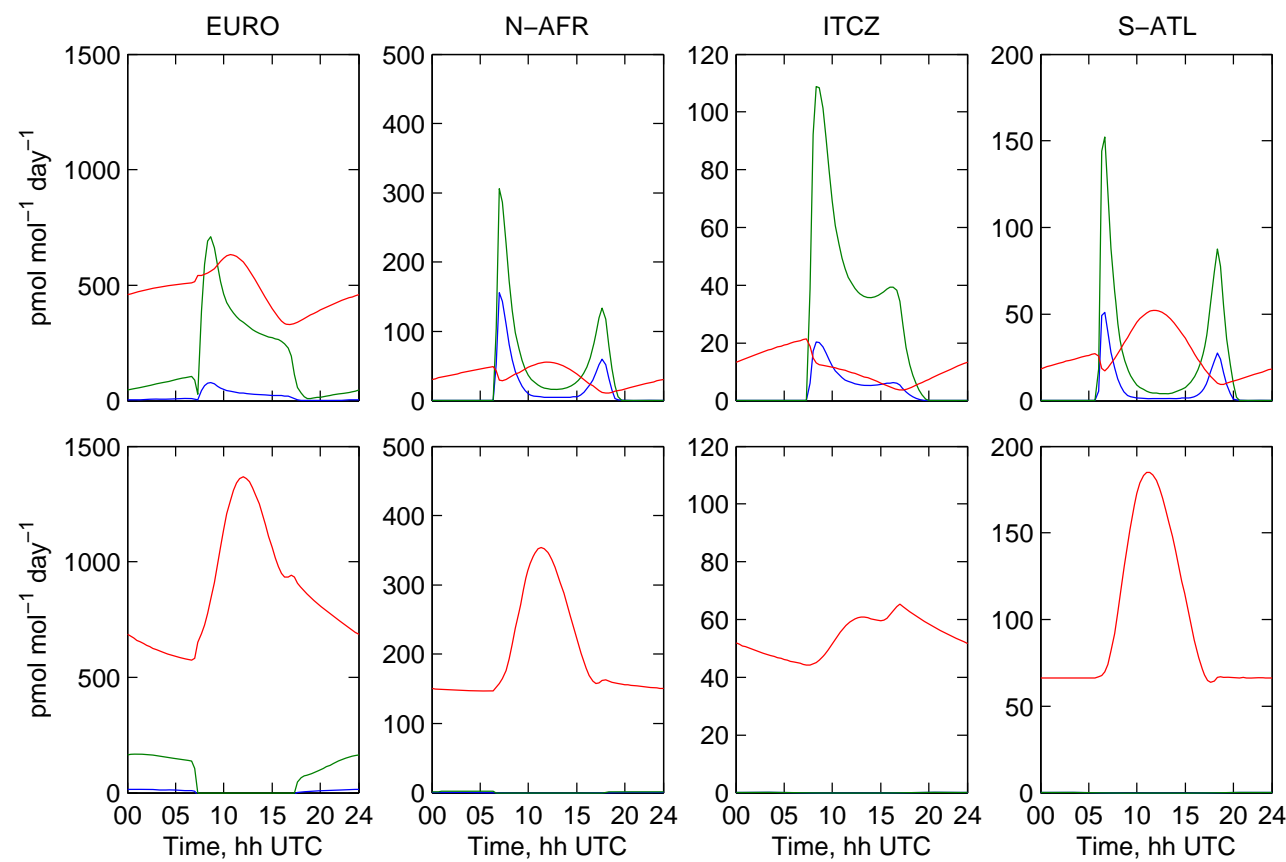

Fig. 10. Simulated diel cycles in selected $\mathrm{NO}_{\mathrm{x}}$ sinks for the four flow regimes. Values for runs "with halogens" are depicted in the top row of panels and those for "no halogens" are in the bottom row. Gas-phase sinks are in red, heterogeneous reactions involving sea salt are in blue, and those involving $\mathrm{S}$ aerosol are in green. Gas-phase reactions include $\mathrm{NO}_{2}+\mathrm{O}_{3}, \mathrm{NO}_{2}+\mathrm{OH}$, and $\mathrm{NO}_{3}+\left(\mathrm{CH}_{3}\right)_{2} \mathrm{~S}$; $\mathrm{HNO}_{3}$ photolysis is evaluated as a negative sink. Heterogeneous pathways include hydrolysis and reactions with particulate $\mathrm{Cl}^{-}$and $\mathrm{Br}^{-}$involving $\mathrm{ClNO}_{3}$, $\mathrm{BrNO}_{3}$, and $\mathrm{N}_{2} \mathrm{O}_{5}$.

that under the polluted conditions in the EURO regime, the overall influences of halogens on $\mathrm{NO}_{\mathrm{x}}$ cycling was significant. Although the peak simulated mixing ratios of $\mathrm{OH}$ and $\mathrm{HO}_{2}$ were similar in the "with halogens" versus "no halogens" runs, lower simulated $\mathrm{NO}_{\mathrm{x}}$ in the "with halogens" run led to net $\mathrm{O}_{3}$ destruction resulting in simulated average daily $\mathrm{O}_{3}$ mixing ratios that were $23 \%$ lower relative to the "no halogens" run (Fig. 8, Table 4). We note that simulated $\mathrm{O}_{3}$ mixing ratios (Table 4) were greater than measured values within the EURO regime (Table 3). Several methodological factors may have contributed to these differences. Chemical transformations involving I-containing compounds were not considered in the simulations but may have contributed to net $\mathrm{O}_{3}$ destruction in ambient air (e.g., Read et al., 2008). In addition, both the entrainment flux of $\mathrm{O}_{3}$ and the ratio of $\mathrm{HNO}_{3}$ to $\mathrm{NO}_{2}$ used to replace depositional losses of oxidized $\mathrm{N}$ are poorly constrained. Sensitivity runs based on higher $\mathrm{HNO}_{3}: \mathrm{NO}_{2}$ ratios than used in the model parameterization yielded steady state $\mathrm{O}_{3}$ mixing ratios within the range of observations.

\subsection{North African influenced}

\subsubsection{Measured characteristics}

Relative to EURO, the N-AFR regime was characterized by generally higher sea-salt concentrations (Figs. 2b, 3j), sim- ilar ranges in particulate $\mathrm{NO}_{3}^{-}$and nss $\mathrm{SO}_{4}^{2-}$ concentrations, lower $\mathrm{HNO}_{3}$ and $\mathrm{SO}_{2}$ mixing ratios (Figs. 2e, f, 3o, p, Table 3) and higher pHs (Figs. 2g, 3q). We infer that the most of the oxidized $\mathrm{N}$ and $\mathrm{S}$ originated as primary or secondary combustion products that were transported from Western Europe, western Africa, and ships at sea. Acidification and associated dechlorination of marine aerosol primarily by $\mathrm{HNO}_{3}$ (Fig. 3n, o) sustained substantial $\mathrm{HCl}$ mixing ratios (Fig. 2c, Table 3). $\mathrm{EF}\left(\mathrm{Cl}^{-}\right)$decreased with decreasing particle size (Fig. 3k) and particulate $\mathrm{Cl}^{-}$deficits summed over all size fractions were generally greater than the corresponding $\mathrm{HCl}$ mixing ratios (Fig. 2c) suggesting that the atmospheric lifetime of $\mathrm{HCl}$ within this regime was somewhat shorter than that of the parent aerosol.

$\mathrm{Cl}^{*}$ was detected during most sampling intervals north of $22^{\circ} \mathrm{N}$ (Fig. 2c). Higher mixing ratios during this period were generally observed at night although consistent diel variability was not evident. Between 22 and $18 \mathrm{~N}, \mathrm{Cl}^{*}$ was undetectable; an instrumental malfunction precluded quantification through the southern segment of this regime.

The highest concentrations of $\mathrm{Br}_{t}$, the greatest absolute particulate $\mathrm{Br}^{-}$deficits $\left(30.1\right.$ and $18.6 \mathrm{pmol} \mathrm{mol}^{-1}$, respectively, Fig. 2d), and the highest particulate $\mathrm{Br}^{-}$concentrations, (Fig. 31) along the cruise track were measured in the N-AFR region. During a previous cruise of the Polarstern, Leser et al. (2003) detected significant $\mathrm{BrO}(>1.0$ 
to $3.6 \mathrm{pmol} \mathrm{mol}^{-1}$ ) over a 2-day period off North Africa between 37 and $30 \mathrm{~N}$. BrO was generally $<1 \mathrm{pmol} \mathrm{mol}^{-1}$ to the north and south of this region. The maximum mixing ratio of $\mathrm{Br}_{t}$ along the cruise track during 2003 was also measured in this region (Fig. 2d). This coincidence in maxima for $\mathrm{BrO}$ (Leser et al., 2003) and $\mathrm{Br}_{t}$ (Fig. 2d) suggests that during October Br-radical chemistry in the eastern Atlantic peaks in this latitudinal band.

As in the EURO regime, bulk aerosol was significantly depleted in $\mathrm{Br}^{-}$relative to fresh sea salt (Fig. 2b, Table 3) but the smallest size fraction was highly enriched (Fig. 31, m). Also, as in EURO, $\mathrm{Br}_{t}$ was present in the N-AFR regime at higher concentrations than particulate $\mathrm{Br}^{-}$(Fig. 2d), which suggests that $\mathrm{Br}_{t}$ had a longer atmospheric lifetime against dry deposition than the parent aerosol. $\mathrm{Br}_{t}$ varied systematically over diel cycles with mixing ratios during daytime systematically greater those at night (Fig. 2d). In contrast, $\mathrm{Br}^{-}$associated with bulk aerosol exhibited relatively less day-night variability.

Median estimated emission fluxes of sea-salt $\mathrm{Br}^{-}$and $\mathrm{Cl}^{-}$were approximately balanced by the corresponding drydeposition fluxes of total $\mathrm{Br}\left(\mathrm{Br}_{t}+\right.$ particulate $\left.\mathrm{Br}^{-}\right)$and total $\mathrm{Cl}\left(\mathrm{HCl}+\right.$ particulate $\mathrm{Cl}^{-}$, Fig. 6), which implies that production of marine aerosol was the primary source for inorganic $\mathrm{Cl}$ and $\mathrm{Br}$ in this regime. $\mathrm{Br}_{t}$ and particulate $\mathrm{Br}^{-}$accounted for approximately equal fractions of the median dry flux of total $\mathrm{Br}$ whereas particulate $\mathrm{Cl}^{-}$dominated the median dry flux of total $\mathrm{Cl}$.

\subsubsection{Simulated characteristics}

Simulated steady-state mixing ratios of $\mathrm{NO}$ and $\mathrm{NO}_{2}$ in the "with halogens" run for the N-AFR regime averaged 3.6 and $27 \mathrm{pmol} \mathrm{mol}^{-1}$, respectively, over diel cycles (Fig. 8), which were within the range of measurements in this region by Carsey et al. (1997) $\left(\mathrm{NO}_{\mathrm{x}}\right.$ range: 17 to $69 \mathrm{pmol} \mathrm{mol}^{-1}$; $\mathrm{NO}_{\mathrm{x}}$ median: $\left.31 \mathrm{pmol} \mathrm{mol}^{-1}\right)$, Leser et al. (2003) $\left(\mathrm{NO}_{2}\right.$ range: $<24$ to $462 \mathrm{pmol} \mathrm{mol}^{-1}$ ), Read et al. (2008) (daytime average NO for October and November: 2.7 and $4.5 \mathrm{pmol} \mathrm{mol}^{-1}$, respectively), Lawler et al. (2009) $\left(\mathrm{NO}_{\mathrm{x}}\right.$ range: $<14$ to $51 \mathrm{pmol} \mathrm{mol}^{-1}$ during May and June), and Lee et al. (2009) (average $\mathrm{NO}_{\mathrm{x}}$ for October and November: 18.5 and $20.5 \mathrm{pmol} \mathrm{mol}^{-1}$, respectively). The simulated size distributions of $\mathrm{NO}_{3}^{-}, \mathrm{nss}_{4}^{2-}$, and $\mathrm{Cl}^{-}$in the "with halogens" runs (Fig. 9) were similar to the corresponding median values for measured distributions (Fig. 3n, o, $\mathrm{j}$, respectively). The simulated mixing ratios of $\mathrm{HNO}_{3}(92$ to $108 \mathrm{pmol} \mathrm{mol}^{-1}$, not shown) were greater than measured mixing ratios (Fig. 2e, Table 3). Simulated $\mathrm{SO}_{2}$ (389 to $401 \mathrm{pmol} \mathrm{mol}^{-1}$, not shown) fell within the upper range of observations (Fig. 2f, Table 3), and simulated $\mathrm{HCl}$ (Fig. 8, 254 to $289 \mathrm{pmol} \mathrm{mol}^{-1}$ ) fell within the lower range of observations (Fig. 2c, Table 3). With the exception of the largest and smallest size fractions, simulated aerosol $\mathrm{pHs}$ for the "with halogens" run (Fig. 8, all 3.7) were similar to median values inferred from the measured phase partitioning of $\mathrm{HCl}$ (Fig. 3p, 3.8 to 3.9).

Simulated $\mathrm{Cl}^{*}$ mixing ratios (11 to $26 \mathrm{pmol} \mathrm{mol}^{-1}$ ) were within the range of measured $\mathrm{Cl} *$ (Fig., 2c, Table 3 ) and were dominated during the daytime by $\mathrm{HOCl}$ and at night by $\mathrm{BrCl}$ (Fig. 8, Table 4). The simulated nocturnal mixing ratios of $\mathrm{Cl}_{2}$ (maximum of $2.8 \mathrm{pmol} \mathrm{mol}^{-1}$ ) were at the lower limit and those of $\mathrm{BrCl}$ (maximum of $16 \mathrm{pmol} \mathrm{mol}^{-1}$ ) were greater than corresponding measured mixing ratios in aged polluted air at Cape Verde (maximum of 35 and $<2 \mathrm{pmol} \mathrm{mol}^{-1}$, respectively; Lawler et al., 2009). These differences relate in part to the fact that our model calculations were based on steady-state conditions whereas Lawler et al. (2009) evaluated a chemically evolving pollutant plume. Cl-atom production in our model was dominated by $\mathrm{BrCl}$ photolysis and $\mathrm{ClO}+\mathrm{NO} ; \mathrm{ClNO}_{2}$ photolysis was insignificant (Table 4). Atomic $\mathrm{Cl}$ peaked in early morning at concentrations of $7.8 \times 10^{4} \mathrm{~cm}^{-3}$ and remained high throughout the day (Fig. 8). Similar concentrations of atomic $\mathrm{Cl}$ were simulated by (Lawler et al., 2009) although the primary precursor under those conditions was $\mathrm{Cl}_{2}$ sustained by autocatalytic cycling. At these concentrations, atomic $\mathrm{Cl}$ was an important oxidant for alkanes and $\left(\mathrm{CH}_{3}\right)_{2} \mathrm{~S}$ and accounted for $36 \%$ of simulated $\mathrm{CH}_{4}$ oxidation in this regime.

The simulated size distribution of $\mathrm{Br}^{-}$(Fig. 8) differed considerably from measured distributions (Fig. 31). All simulated size fractions except the largest two were almost completely debrominated. In contrast, measured distributions reveal large enrichment relative to sea salt in the finest size fraction and retention of significant $\mathrm{Br}^{-}$in all super- $\mu \mathrm{m}$ size fractions (Fig. 31, m). As discussed above, causes for these differences are unknown. The median measured $\mathrm{EF}\left(\mathrm{Br}^{-}\right)$for bulk aerosol $(0.25)$ implies that volatile inorganic $\mathrm{Br}$ in the model is overestimated. The retention of $\mathrm{Br}$ in the aerosol coupled with the high concentrations and rapid turnover of sea salt and the longer lifetime against deposition of $\mathrm{Br}_{t}$ relative to the parent aerosol contributed to the factor of two higher mixing ratios of simulated $\mathrm{Br}_{t}$ (averaging $37 \mathrm{pmol} \mathrm{mol}^{-1}$ over diel cycles, Fig. 8, Table 4) compared to measured values (Fig. 2d, Table 3). In the model, $\mathrm{BrCl}$ and $\mathrm{Br}_{2}$ dominated $\mathrm{Br}_{t}$ at night and $\mathrm{HBr}, \mathrm{BrNO}_{3}$, and $\mathrm{HOBr}$ dominated during the day (Fig. 6, Table 4). The dominant sources for atomic $\mathrm{Br}$ were $\mathrm{BrO}+\mathrm{NO}$ and the photolysis of $\mathrm{HOBr}, \mathrm{Br}_{2}$, and $\mathrm{BrCl}$ (Table 4).

Reaction with atomic $\mathrm{Br}$ and $\mathrm{Cl}$ accounted for $46 \%$ and $2 \%$, respectively, of the total modeled $\mathrm{O}_{3}$ sink. Simulated $\mathrm{BrO}$ mixing ratios peaked following sunrise at $7.8 \mathrm{pmol} \mathrm{mol}^{-1}$. The average simulated mixing ratio during midday $\left(4.7 \mathrm{pmol} \mathrm{mol}^{-1}\right)$ was near the upper limits for both long-term measurements of $\mathrm{BrO}$ at Cape Verde (daytime average of $2.5 \pm 1.1 \mathrm{pmol} \mathrm{mol}$; Read et al., 2008) and measurements within the N-AFR regime during a previous cruise of the Polarstern (less than $3.6 \mathrm{pmol} \mathrm{mol}^{-1}$; Leser et al., 2003). The retention/accumulation of $\mathrm{Br}^{-}$in the ambient 
aerosol but not in the model coupled with the longer lifetime of volatile relative to particulate $\mathrm{Br}$ contributed to these differences. In addition, sea-salt concentrations within this regime during the cruise (Table 3) were generally much greater than those reported at Cape Verde during spring (74 to $254 \mathrm{nmol} \mathrm{Na}^{+} \mathrm{m}^{-3}$; Lawler et al., 2009). This implies that the emission flux of particulate $\mathrm{Br}^{-}$associated with sea-salt production and the corresponding mixing ratios of volatile inorganic $\mathrm{Br}$ based on median conditions for the N-AFR regime were greater than those at Cape Verde, which would have also contributed to the higher $\mathrm{BrO}$ simulated for this regime relative to $\mathrm{BrO}$ measured at Cape Verde.

Halogen chemistry accelerated the oxidation of $\mathrm{NO}_{\mathrm{x}}$ to $\mathrm{HNO}_{3}$ and particulate $\mathrm{NO}_{3}^{-}$relative to rates predicated based on conventional $\mathrm{HO}_{\mathrm{x}} / \mathrm{NO}_{\mathrm{x}}$ chemistry (Fig. 10) yielding $\mathrm{NO}_{\mathrm{x}}$ mixing ratios that were lower by a factor of two in the "with halogens" versus "no halogens" runs (Fig. 8, Table 4). Following sunrise, the photolysis of $\mathrm{Br}_{2}, \mathrm{BrCl}$, and $\mathrm{Cl}_{2}$ initiated active halogen-radical chemistry and the associated oxidation of $\mathrm{NO}_{\mathrm{x}}$ via production of halogen nitrates and subsequent heterogeneous reactions with aerosols, primarily during early morning. Reactions involving $\mathrm{S}$ aerosol accounted for $69 \%$ of the total heterogeneous sink and hydrolysis of $\mathrm{BrNO}_{3}$ and $\mathrm{ClNO}_{3}$ to produce hypohalous acids were the most important pathways (Table 4). The subset of reactions involving sea salt was dominated by $\mathrm{BrNO}_{3}+\mathrm{Cl}^{-} \rightarrow \mathrm{BrCl}+\mathrm{NO}_{3}^{-}(60 \%)$.

Relative to the "with halogens" run, daily maxima in simulated $\mathrm{OH}$ and $\mathrm{HO}_{2}$ in the "no halogens" run (Table 4) were higher by factors of 2.8 , and 1.5 , respectively. These differences were driven primarily by the destruction of $\mathrm{HO}_{2}$ via reaction with $\mathrm{BrO}$ and the lower production of $\mathrm{OH}$ resulting from lower $\mathrm{HO}_{2}, \mathrm{NO}$ and $\mathrm{O}_{3}$ in the "with halogens" run (Table 4). In contrast to these results, Read et al. (2008) report that, when halogen chemistry is not included in their box model calculations for conditions at Cape Verde, $\mathrm{OH}$ is lower by $5 \%$ to $12 \%$. However, in the Read et al. (2008) model calculations both with and without halogens, NO is constrained by the same measured mixing ratios. While this approach may have characterized the direct influences of halogens on $\mathrm{OH}$, the large indirect influences on $\mathrm{OH}$ resulting from the accelerated oxidation of $\mathrm{NO}_{\mathrm{x}}$ via halogen chemistry (Fig. 10) was not considered explicitly. Model calculations reported herein indicate that, when these indirect influences are included, halogen chemistry leads to a net decrease not increase in $\mathrm{OH}$ concentrations under conditions for the N-AFR regime. The lower concentrations of simulated $\mathrm{OH}$ and $\mathrm{HO}_{2}$ in the "with halogen" runs for both this regime and those to the south have important implications for oxidation processes in the MBL and the corresponding atmospheric lifetimes of climatically important trace gases including $\mathrm{CH}_{4}$.

The combined interrelated influences of $\mathrm{Br}$ and $\mathrm{Cl}$ via direct reaction, accelerated oxidation of $\mathrm{NO}_{\mathrm{x}}$, and shifts in the concentrations and relative abundance of $\mathrm{OH}$ and $\mathrm{HO}_{2}$ yielded simulated $\mathrm{O}_{3}$ mixing ratios averaging $14 \mathrm{nmol} \mathrm{mol}^{-1}$
(Fig. 8), which was outside the observed range (Table 3) and substantially lower than that for the "no halogens" run (Fig. 8, Table 4). In addition to the less vigorous multiphase cycling of ambient relative to simulated $\mathrm{Br}$ discussed above, several other factors contributed to differences between measured $\mathrm{O}_{3}$ versus that simulated in the "with halogens" runs. Rates of $\mathrm{O}_{3}$ entrainment (an important $\mathrm{O}_{3}$ source in this region; Read et al., 2008) may be underestimated in the model. The simulations assume clear-sky conditions. Because scattered clouds were present during most of the cruise and attenuated ambient photon fluxes, rates of $\mathrm{Br}$ and $\mathrm{Cl}$ photochemistry and associated net $\mathrm{O}_{3}$ destruction in the model corresponded to upper limits. Finally, iodine-radical chemistry is an important sink for $\mathrm{O}_{3}$ in this region (Read et al., 2008) that was not considered in our simulations. If influences of iodine are excluded, the relative contribution of transformations involving $\mathrm{Br}$ to the other major $\mathrm{O}_{3}$ sinks modeled by Read et al. (2008) for conditions at Cape Verde during March (23\%) are a factor of two less than those simulated herein during autumn $(46 \%)$.

\subsection{ITCZ}

\subsubsection{Measured characteristics}

The relatively low wind velocities within the ITCZ regime (Fig. 2a), perhaps coupled with relatively greater wet removal via the higher frequency of scattered showers, resulted in the lowest sea-salt concentrations measured along the cruise track (Figs. 2b, 3o). The lowest concentrations of total $\mathrm{NO}_{3}$ (Fig. 2e) and total nss $\mathrm{S}$ (Fig. 2f) and corresponding dry-deposition fluxes (Fig. 5) were also observed within this regime. The relatively low $\mathrm{HCl}$ mixing ratios (Fig. 2c), high $\mathrm{EF}\left(\mathrm{Cl}^{-}\right)$s (Fig. 2b), and high aerosol pHs (Fig. 3q) reflect the low concentrations of acids. $\mathrm{Cl}^{*}$ was undetectable during most sampling intervals within this regime (Fig. 2c) but, between $5^{\circ}$ and $2^{\circ} \mathrm{N}$, nocturnal mixing ratios increased from $<24 \mathrm{pmol} \mathrm{mol}^{-1}$ to a predawn peak of $136 \mathrm{pmol} \mathrm{mol}^{-1}$. This episode coincided with increasing RH (Fig. 2a) and nss $\mathrm{SO}_{4}^{2-}$ concentrations (Fig. 2e).

$\mathrm{Br}_{t}$ and particulate $\mathrm{Br}^{-}$deficits were low relative to those in other regions (Fig. 2d). Based on median values, sizeresolved $\mathrm{EF}\left(\mathrm{Br}^{-}\right)$was systematically lower than corresponding values for northerly segments of the cruise and, notably, no enrichment was evident in the smallest size fraction (Fig. 3.). As in the other regimes, the dry-deposition fluxes of total inorganic $\mathrm{Cl}$ and $\mathrm{Br}$ were approximately balanced by the corresponding emission flux of $\mathrm{Cl}^{-}$and $\mathrm{Br}^{-}$associated with sea salt (Fig. 5) suggesting that nss sources of inorganic $\mathrm{Cl}$ and $\mathrm{Br}$ were unimportant. 


\subsubsection{Simulated characteristics}

Simulated steady-state mixing ratios of $\mathrm{NO}_{\mathrm{x}}$ in the "with halogens" run averaged $8.3 \mathrm{pmol} \mathrm{mol}^{-1}$ over diel cycles (Fig. 8). The corresponding $\mathrm{NO}_{2}\left(7.8 \mathrm{pmol} \mathrm{mol}^{-1}\right.$, not shown) was less than the upper limits estimated by Leser et al. (2003) based on measurements in this region $(<24$ to $<100 \mathrm{pmol} \mathrm{mol}^{-1}$ ). The simulated size distributions of nss $\mathrm{SO}_{4}^{2-}$, and $\mathrm{Cl}^{-}$(Fig. 9) were similar to the median measured distributions (Fig. 3o, j, respectively). Although the shapes of the measured and simulated size distributions for $\mathrm{NO}_{3}^{-}$ were similar (Figs. 3n and 9, respectively), the simulated concentrations were greater by a factor of about two. The simulated mixing ratios of $\mathrm{HNO}_{3}$ (28 to $37 \mathrm{pmol} \mathrm{mol}^{-1}$, not shown) and $\mathrm{SO}_{2}$ (57 to $71 \mathrm{pmol} \mathrm{mol}^{-1}$, not shown) were also greater than measured values (Fig. 2e,f, Table 3). Scavenging and wet deposition via precipitation was not considered in the model but probably contributed to the relatively lower measured versus simulated concentrations of soluble species in this regime. Simulated $\mathrm{HCl}$ (Fig. 8, 16 to $22 \mathrm{pmol} \mathrm{mol}^{-1}$ ) was within the lower range of observations (Fig. 2c, Table 3). Simulated $\mathrm{pHs}$ for the middle five size fractions in the "with halogens" run (Fig. 8, 3.4 to 3.7) were generally lower than median values inferred from the measured phase partitioning of $\mathrm{HCl}$ (Fig. 3p, 3.3 to 4.6).

Simulated Cl* mixing ratios (Fig. 8, 20 to $30 \mathrm{pmol} \mathrm{mol}^{-1}$ ) were within the range of measured $\mathrm{Cl}^{*}$ (Fig., 2c, Table 3) and dominated by $\mathrm{HOCl}$ during daytime and $\mathrm{HOCl}, \mathrm{BrCl}$, and $\mathrm{Cl}_{2}$ at night (Fig. 8, Table 4). Photolysis of $\mathrm{BrCl}$ and $\mathrm{HOCl}$ and $\mathrm{ClO}+\mathrm{NO}$ were the dominant sources for atomic $\mathrm{Cl}$ in the model, which peaked during midday at concentrations of $2.1 \times 10^{4} \mathrm{~cm}^{-3}$ (Fig. 8, Table 4). At these concentrations, $\mathrm{Cl}$ was an important oxidant for alkanes and accounted for $48 \%$ of the modeled sink for $\mathrm{CH}_{4}$ in this region.

The simulated size distribution of $\mathrm{Br}^{-}$(Fig. 9) was similar to the median for measured distributions (Fig. 31). Most individual $\mathrm{Br}^{-}$concentrations for the impactor samples were below DLs and all simulated size fractions were almost completely debrominated. However, the median measured $\mathrm{EF}\left(\mathrm{Br}^{-}\right)$in bulk aerosol (0.35), for which analytical resolution was better, indicates that significant amounts of $\mathrm{Br}^{-}$ were retained by or accumulated in ambient aerosol (Fig. 2b). Simulated $\mathrm{Br}_{t}$ averaged $8.3 \mathrm{pmol} \mathrm{mol}^{-1}$ over diel cycles, which was greater than all measured values (Fig. 2d; Table 3). As in the other regimes, retention of $\mathrm{Br}$ in the aerosol contributed to lower mixing ratios of measured versus simulated $\mathrm{Br}_{t}$. In the model, $\mathrm{Br}_{t}$ was dominated by $\mathrm{BrCl}$ at night and $\mathrm{BrNO}_{3}, \mathrm{HOBr}$, and $\mathrm{BrO}$ during the day (Fig. 8, Table 4). The primary sources for atomic $\mathrm{Br}$ were photolysis of $\mathrm{BrCl}$ and $\mathrm{HOBr}$ and $\mathrm{BrO}+\mathrm{NO}$ (Table 4).

Reaction with atomic $\mathrm{Br}$ and $\mathrm{Cl}$ accounted for $35 \%$ and $5 \%$, respectively, of the total chemical sink for $\mathrm{O}_{3}$ within this regime. However, simulated $\mathrm{BrO}$ mixing ratios during midday (maximum and midday average of 3.0 and $2.5 \mathrm{pmol} \mathrm{mol}^{-1}$ ) were greater than values measured in this region during a previous cruise $\left(<1 \mathrm{pmol} \mathrm{mol}^{-1}\right.$; Leser et al., 2003), which suggests that the simulations may overestimate the influence of $\mathrm{Br}$ on $\mathrm{O}_{3}$. The accelerated oxidation of $\mathrm{NO}_{\mathrm{x}}$ by halogen chemistry (Fig. 10) yielded steady-state $\mathrm{NO}_{\mathrm{x}}$ mixing ratios that were lower by a factor of three relative to the "no halogens" run (Fig. 8, Table 4). Reactions involving $\mathrm{S}$ aerosol accounted for $86 \%$ of the total heterogenous sink, which was dominated by hydrolysis reactions involving $\mathrm{ClNO}_{3}$ and $\mathrm{BrNO}_{3}$ (Table 4). Pathways involving sea salt were dominated by $\mathrm{ClNO}_{3}$ and $\mathrm{BrNO}_{3}$ reaction with $\mathrm{Cl}^{-}$to produce $\mathrm{Cl}_{2}$ and $\mathrm{BrCl}$ (29\% and $21 \%$, respectively) and $\mathrm{ClNO}_{3}$ and $\mathrm{BrNO}_{3}$ hydrolysis $(24 \%$ and $17 \%$, respectively). Relative to the "with halogens" runs, daily maxima in simulated $\mathrm{OH}$ and $\mathrm{HO}_{2}$ in the "no halogens" run (Table 4) were also higher by factors of 1.44 and 1.35 , respectively. As for the N-AFR regime, these differences were driven primarily by enhanced destruction of $\mathrm{HO}_{2}$ by $\mathrm{BrO}$ and reduced production of $\mathrm{OH}$ via reaction of $\mathrm{HO}_{2}$ with $\mathrm{NO}$ and $\mathrm{O}_{3}$ in the "with halogens" run (Table 4). The combined influences of $\mathrm{Br}$ and $\mathrm{Cl}$ via direct reaction, accelerated oxidation of $\mathrm{NO}_{\mathrm{x}}$, and reductions in $\mathrm{OH}$ and $\mathrm{HO}_{2}$ concentrations yielded simulated $\mathrm{O}_{3}$ mixing ratios averaging $29 \mathrm{nmol} \mathrm{mol}^{-1}$ (Fig. 8, Table 4) in good agreement with measured values (Table 3 ). Simulated $\mathrm{O}_{3}$ for the "no halogens" run (Fig. 8, Table 4) was greater than measured values (Table 3 ). As for the NAFR regime, several factors may influence comparability of measured versus simulated $\mathrm{O}_{3}$ in the "with halogens" run; these including the entrainment flux of $\mathrm{O}_{3}$, attenuation of radiation by clouds, sequestering of significant $\mathrm{Br}$ in ambient aerosols, and iodine chemistry. In addition, the calculation of the scaling coefficients did not consider the conditional instability of the region which, when corrected for stability, would yield vertical scaling coefficients closer to unity for the larger aerosol size-bins. Simulations (not reported) parameterized with the measured (i.e., non-scaled) aerosol concentrations at $23 \mathrm{~m}$ indicate that the modeled results are sensitive to the vertical scaling approach, particularly at the lower wind velocities for this regime, which correspond to relatively greater vertical gradients in sea-salt mass (Table 2).

\subsection{South Atlantic}

\subsubsection{Measured characteristics}

The S-ATL regime was characterized by increasing $\mathrm{HNO}_{3}$, particulate $\mathrm{NO}_{3}^{-}$(Fig. 2e), and sea-salt concentrations (Fig. 2b). Relative to the ITCZ, the increasing levels of acidity sustained generally lower $\mathrm{EF}\left(\mathrm{Cl}^{-}\right)$s and higher $\mathrm{HCl}$ (Fig. 2b, d, Table 3). Median inferred $\mathrm{pHs}$ for the sea-salt size fractions in this regime were similar to those in the $\mathrm{N}$-AFR regime but $\mathrm{pHs}$ for the sub- $\mu \mathrm{m}$ size fractions were lower (Fig. 3p). Median dry-deposition fluxes of total $\mathrm{NO}_{3}$ and total nss $\mathrm{S}$ were lower by factors of 2.1 and 2.7, respectively, than those for N-AFR (Fig. 5) indicating that combustion products were relatively less important in this regime. In 
addition, and in contrast to other regions, $\mathrm{SO}_{2}$ in the S-ATL regime exhibited fairly consistent diel variability with higher mixing ratios during daytime and lower at night (Fig. 2f). This pattern would be consistent with the hypothesis that most $\mathrm{SO}_{2}$ in this region was produced photochemically during the daytime via oxidation of marine-derived $\left(\mathrm{CH}_{3}\right)_{2} \mathrm{~S}$ by $\mathrm{OH}, \mathrm{BrO}$, and $\mathrm{Cl}$ and subsequently lost via a combination of deposition to the surface and oxidation to particulate $\mathrm{H}_{2} \mathrm{SO}_{4}$ through multiphase pathways (e.g., Vogt et al., 1996). Combustion-derived $\mathrm{SO}_{2}$ would not be expected to exhibit diel variability of this nature.

Concentrations of both $\mathrm{Br}_{t}$ and particulate $\mathrm{Br}^{-}$deficits were generally greater than those in the ITCZ (Fig. 2d). In contrast to EURO and $\mathrm{N}$-AFR, $\mathrm{Br}_{t}$ in the $\mathrm{S}$-ATL regime did not exhibit systematic diel variability. $\mathrm{EF}\left(\mathrm{Br}^{-}\right)$was generally less than 0.3 (Fig. 2b) and all size fractions were significantly depleted relative to sea salt (Fig. 3m). During most sampling periods, $\mathrm{Br}_{t}$ was present at higher concentrations than the corresponding particulate $\mathrm{Br}^{-}$deficits (Fig. 2d) and dominated the median dry-deposition flux of total inorganic $\mathrm{Br}$ (Fig. 6b). In addition, the median emission flux of $\mathrm{Br}^{-}$in association with sea salt was approximately balanced by the corresponding dry deposition of total inorganic $\mathrm{Br}$. These relationships indicate that nascent aerosols were efficiently debrominated under these conditions and that $\mathrm{Br}_{t}$ had a longer lifetime against deposition than the parent aerosol.

\subsubsection{Simulated characteristics}

Simulated steady-state mixing ratios of $\mathrm{NO}_{\mathrm{x}}$ in the "with halogens" run averaged $20 \mathrm{pmol} \mathrm{mol}^{-1}$ over diel cycles (Fig. 8). The corresponding $\mathrm{NO}_{2}\left(17 \mathrm{pmol} \mathrm{mol}^{-1}\right.$, not shown) was within the range estimated by Leser et al. (2003) based on measurements in this region $(<24$ to $<100 \mathrm{pmol} \mathrm{mol}^{-1}$ ). The simulated size distributions of nss $\mathrm{SO}_{4}^{2-}$ and $\mathrm{Cl}^{-}$in the "with halogens" runs (Fig. 9) were similar to the corresponding median measured distributions (Fig. 3o, j, respectively). As for the ITCZ, the shape of the simulated size distribution for $\mathrm{NO}_{3}^{-}$(Fig. 8) was similar to measured distributions (Fig. 3n) but the corresponding concentrations were greater by a factor of about two. The simulated $\mathrm{HNO}_{3}$ (56 to $65 \mathrm{pmol} \mathrm{mol}^{-1}$, not shown) was within the upper range of measured values (Fig. 2e, Table 3); simulated $\mathrm{SO}_{2}$ (105 to $121 \mathrm{pmol} \mathrm{mol}^{-1}$, not shown), which originated primarily from the oxidation of $\left(\mathrm{CH}_{3}\right)_{2} \mathrm{~S}$, was outside the range of observations (Fig. 2f, Table 3); and simulated $\mathrm{HCl}$ (Fig. 8, 114 to $128 \mathrm{pmol} \mathrm{mol}^{-1}$ ) was within the lower range of observations (Fig. 2c, Table 3). Simulated pHs for the middle five size fractions in the "with halogens" run (Fig. 8, 3.8 to 4.0 ) were within the range of median values inferred from the measured phase partitioning of $\mathrm{HCl}$ (Fig. 3p, 3.5 to 3.9).

Simulated $\mathrm{Cl}^{*}$ mixing ratios were within the range of measured $\mathrm{Cl}^{*}$ (Fig. 2c, Table 3 ) and dominated by $\mathrm{HOCl}$ during the day and $\mathrm{BrCl}$ at night (Fig. 8, Table 4). $\mathrm{Cl}_{2}$ peaked at
$2.0 \mathrm{pmol} \mathrm{mol}^{-1}$ and accounted for $12 \%$ of $\mathrm{Cl}^{*}$ before dawn (Fig. 8). Photolysis of $\mathrm{BrCl}$ and $\mathrm{HOCl}$ and $\mathrm{ClO}+\mathrm{NO}$ were the dominant sources for atomic $\mathrm{Cl}$, which peaked during midday at concentrations of $4.1 \times 10^{4} \mathrm{~cm}^{-3}$ (Fig. 8, Table 4). Atomic $\mathrm{Cl}$ accounted for $19 \%$ of simulated $\mathrm{CH}_{4}$ oxidation in this regime.

The simulated size distribution of $\mathrm{Br}^{-}$(Fig. 8) was similar to the median for measured distributions (Fig. 31). Most individual $\mathrm{Br}^{-}$concentrations for the impactor samples were below DLs and all simulated size fractions except the largest were almost completely debrominated. The median measured $\mathrm{EF}\left(\mathrm{Br}^{-}\right)$for bulk aerosol (0.14) also indicates relatively less $\mathrm{Br}^{-}$associated with ambient aerosol compared to other regimes (Fig. 2b). Like the measurements, simulated $\mathrm{Br}_{t}$ exhibited little diel variability (Fig. 8) but measured mixing ratios (Fig. 2d, Table 3) were lower by factors of three to four relative to simulated values (Fig. 8, Table 4). Retention of $\mathrm{Br}^{-}$in the aerosol coupled with the longer lifetime against deposition for $\mathrm{Br}_{t}$ relative to the parent aerosols contributed to these differences. $\mathrm{Br}_{t}$ in the model, was dominated by $\mathrm{BrCl}$ and $\mathrm{Br}_{2}$ at night and $\mathrm{HBr}, \mathrm{BrNO}_{3}$, and $\mathrm{HOBr}$ during the day (Fig. 8, Table 4). The primary sources for atomic $\mathrm{Br}$ were photolysis of $\mathrm{HOBr}, \mathrm{BrCl}$, and $\mathrm{Br}_{2}$ and $\mathrm{BrO}+\mathrm{NO}$ (Table 4).

As in the ITCZ regime, reaction with atomic $\mathrm{Br}$ was a significant sink for simulated $\mathrm{O}_{3}(30 \%)$. Simulated $\mathrm{BrO}$ (maximum and average midday mixing ratios of 6.5 and $2.8 \mathrm{pmol} \mathrm{mol}^{-1}$, respectively, Fig. 8) was greater than measured values within this region during a previous cruise $\left(<1 \mathrm{pmol} \mathrm{mol}^{-1}\right.$; Leser et al., 2003). As in the other regimes, halogen chemistry accelerated the oxidation of $\mathrm{NO}_{\mathrm{x}}$ to $\mathrm{HNO}_{3}$ and particulate $\mathrm{NO}_{3}^{-}$relative to rates predicated based on conventional $\mathrm{HO}_{\mathrm{x}} / \mathrm{NO}_{\mathrm{x}}$ chemistry (Fig. 10) yielding $\mathrm{NO}_{\mathrm{x}}$ mixing ratios that were lower by a factor of about two in the "with halogens" versus "no halogens" runs (Fig. 8, Table 4). As in other regimes, reactions involving halogen nitrates and $\mathrm{S}$ aerosol dominated $(79 \%)$ the total heterogeneous sink with the hydrolysis of $\mathrm{BrNO}_{3}$ and $\mathrm{ClNO}_{3}$ accounting for most of the total (Table 4). Production of $\mathrm{BrCl}$ via $\mathrm{BrNO}_{3}+\mathrm{Cl}^{-}$accounted for $55 \%$ of the heterogeneous reactions involving sea salt. Relative to the "with halogens" run, daily maxima in simulated $\mathrm{OH}$ and $\mathrm{HO}_{2}$ in the "no halogens" run (Table 4) were greater by factors of 1.66 and 1.33 , respectively. These differences are driven primarily by enhanced destruction of $\mathrm{HO}_{2}$ by $\mathrm{BrO}$ and reduced production of $\mathrm{OH}$ via $\mathrm{HO}_{2}+\mathrm{NO}$ and $\mathrm{HO}_{2}+\mathrm{O}_{3}$ in the "with halogens" run (Table 4). The combined influences of $\mathrm{Br}$ and $\mathrm{Cl}$ via direct reaction, accelerated oxidation of $\mathrm{NO}_{\mathrm{x}}$ and changes in $\mathrm{OH}$ and $\mathrm{HO}_{2}$ yielded simulated $\mathrm{O}_{3}$ mixing ratios averaging $14 \mathrm{nmol} \mathrm{mol}^{-1}$, which were at the lower limit of measured values (Table 3 ) and a factor of two less than that simulated in the "no halogens" run (Fig. 8, Table 4). The same caveats mentioned above regarding comparisons between measured and simulated $\mathrm{O}_{3}$ for other regimes apply to the S-ATL. 


\subsection{Implications}

As discussed above, the model reproduced many measured characteristics of the multiphase system with reasonable confidence, which implies that simulated characteristics that were not constrained by observations provide useful insight concerning the underlying physicochemical processes. In addition, when evident, large divergence between simulated and measured values suggest potential problems related to the parameterization scheme for the model and/or limitations in our current understanding of major processes.

Relative to the large variability in median fluxes and concentrations of sea salt, acidic gases, and precursors and corresponding variability in aerosol $\mathrm{pH}$ across the four regimes, simulated maxima for daytime concentrations of atomic $\mathrm{Cl}$ varied over a narrow range of $2.1 \times 10^{4}$ to $7.8 \times 10^{4} \mathrm{~cm}^{-3}$. The lowest simulated $\mathrm{Cl}$-atom concentrations were in the ITCZ regime, which contained the lowest median concentrations of sea salt and acids. The highest levels were in the $\mathrm{N}$-AFR regime, which contained the highest concentrations of sea salt but lower levels of combustion products and $\mathrm{HCl}$ relative to the EURO regime. The substantial $\mathrm{Cl}$-atom concentrations simulated over this wide range in physicochemical conditions and their consistency with published estimates based on measurements elsewhere (e.g., Pszenny et al., 2007; Lawler et al., 2009; and references therein) supports the hypothesis that $\mathrm{Cl}$-radical chemistry contributes significantly to oxidation potential with implications for the corresponding atmospheric lifetimes of alkanes and $\left(\mathrm{CH}_{3}\right)_{2} \mathrm{~S}$ within the MBL over broad geographic regions. BrO was also an important oxidant for $\left(\mathrm{CH}_{3}\right)_{2} \mathrm{~S}$ in the model. For the "with halogens" runs, reaction with atomic $\mathrm{Cl}$ and $\mathrm{BrO}$ accounted for $6 \%$ and $7 \%$, respectively, of $\left(\mathrm{CH}_{3}\right)_{2} \mathrm{~S}$ oxidation in the EURO regime; $16 \%$ and $59 \%$, respectively, in N-AFR; $12 \%$ and $72 \%$, respectively, in the ITCZ; and $14 \%$ and $57 \%$, respectively, in S-ATL. Because mixing ratios of $\mathrm{OH}$ (the other major oxidant for $\left.\left(\mathrm{CH}_{3}\right)_{2} \mathrm{~S}\right)$ in the "with halogen" runs were lower, these percentage contributions of halogens reflect both the enhanced oxidation by halogens and diminished oxidation by $\mathrm{OH}$ relative to "no halogens" runs. Overall, the atmospheric lifetimes of $\left(\mathrm{CH}_{3}\right)_{2} \mathrm{~S}$ within the EURO and $\mathrm{N}$ AFR regime in the "with halogens" and "no halogens" runs were similar but those with the ITCZ and S-ATL were lower by factors of 5.9 and 1.8 , respectively. The oxidation of $\left(\mathrm{CH}_{3}\right)_{2} \mathrm{~S}$ by $\mathrm{Cl}$ may also influence the distribution of products with implications for aerosol nucleation, growth, and climate feedbacks (e.g., Stickel et al., 1992).

At aerosol solution pHs of 5 to 6 , the aqueous-phase oxidation of S(IV) by hypohalous acids accelerates production of $\mathrm{S}(\mathrm{VI})$ relative to other oxidation pathways and thereby reduces the potential for nucleation and growth of new particles and associated influences on radiative transfer (Keene et al., 1998). Because this pathway is strongly $\mathrm{pH}$ dependent, direct comparisons between relative rates of $\mathrm{S}$ oxidation in the "with halogens" versus "no halogens" runs are mislead- ing because the influence of $\mathrm{HCl}$ phase partitioning on solution $\mathrm{pH}$ was not considered in the latter and, consequently, the low solution pHs in the "no halogens" runs (Fig. 9) are not representative. However, relative contributions of hypohalous acids to total S(IV) oxidation in the "with halogens" runs (Table 4) indicate that, with the exception of the ITCZ, these pathways accounted for minor fractions of $\mathrm{S}(\mathrm{VI})$ production. In all regimes, scavenging of $\mathrm{H}_{2} \mathrm{SO}_{4}$ vapor was the

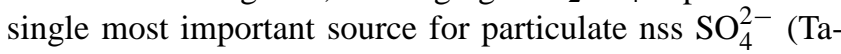
ble 4). Both the measurements and simulations indicate that all aerosol size fractions in all regimes were acidic, a prerequisite for significant halogen activation and autocatalytic cycling (Keene et al., 1998). However, the effective solubility of $\mathrm{SO}_{2}$ over the range of estimated $\mathrm{pHs}$ (most between 3 and 4) is low (e.g., Keene et al., 1998) and, consequently, oxidation of S(IV) by hypohalous acids was relatively unimportant. The combination of higher solution $\mathrm{pHs}$ and $\mathrm{HOCl}$ mixing ratios in the ITCZ regime sustained relatively greater production rates via this pathway. These results suggest that significant aqueous-phase oxidation of S(IV) by hypohalous acids may be limited spatially and temporally to a relatively narrow set of conditions in which 1) Acids and acid precursors are present at sufficiently high concentrations to titrate sea-salt alkalinity (required to drive halogen-activation chemistry), 2) acids and acid precursors are present at sufficiently low concentrations such that solution $\mathrm{pHs}$ remains above $\sim 4.5$ (required for significant $\mathrm{SO}_{2}$ dissolution), and 3) mixing ratios of $\mathrm{HOCl}$ are relatively high.

Several factors influenced variability in the multiphase processing of inorganic $\mathrm{Br}$ and related oxidation processes. First, under conditions of moderate to low levels of pollutants (N-AFR, ITCZ, and S-ATL), both measurements and simulations indicate that most size fractions of marine aerosol were rapidly and substantially debrominated. Consequently, under these conditions, the activation flux of volatile inorganic $\mathrm{Br}$ varied as a function of the corresponding production flux of sea salt $\mathrm{Br}^{-}$from the ocean surface (e.g., Fig. 7a). These results suggest that, for marine regions in which sufficient acidity is present to titrate sea-salt alkalinity and sufficient light is present to drive photochemistry, $\mathrm{Br}$ activation scales roughly proportionately with marine aerosol production and, thus, with the underlying physical drivers (primarily wind velocity, fetch, and sea state).

Second, in the heavily polluted EURO regime, in other polluted marine regions (e.g., Keene et al., 2007a), and to a lesser extent in less polluted regions (Fig. 2b; Sander et al., 2003), significant $\mathrm{Br}$ is apparently sequestered in aerosol solutions by unknown factors and, thus, not considered in current models. This was most evident in the large $\mathrm{Br}$ enrichments measured in the smallest aerosol size factions for the EURO and N-AFR regimes, which, curiously, were not observed in the two southern regimes. Data compiled by Sander et al. (2003) also indicate a tendency for higher $\operatorname{EF}\left(\mathrm{Br}^{-}\right)$s for sub- $\mu \mathrm{m}$ marine aerosols in the Northern relative to the Southern Hemispheres. In addition, the 
shorter-lived, super- $\mu \mathrm{m}$ size fractions, which dominate the production flux of particulate $\mathrm{Br}^{-}$, also retained $\mathrm{Br}^{-}$at levels greater than predicted by the model. The retention of significant $\mathrm{Br}^{-}$in the aerosol effectively reduces $\mathrm{Br}$ activation per unit sea-salt production in ambient air relative to model predictions. Consequently, the modeled mixing ratios of $\mathrm{Br}_{t}$ are considered upper limits and the corresponding influences $\mathrm{Br}$ radicals on chemical processes in the model MBL diverge from those in ambient marine air. The lower modeled versus measured $\mathrm{EF}\left(\mathrm{Br}^{-}\right)$also implies more efficient production of $\mathrm{BrCl}$ versus $\mathrm{Br}_{2}$ via hypohalous reactions with particulate halide ions in the model relative to ambient air (Fickert et al., 1999). Because $\mathrm{BrCl}$ was a major precursor for atomic $\mathrm{Cl}$ in all regimes, the modeled concentrations of atomic $\mathrm{Cl}$ may also represent upper limits.

Third, at high $\mathrm{NO}_{\mathrm{x}}$ mixing ratios in the heavily polluted EURO region, the production of halogen nitrates slowed halogen radical recycling and associated ozone destruction in the gas phase. These transformations coupled with the high levels of $\mathrm{NO}_{\mathrm{x}}$ contributed to the relatively minor influences of halogens on conventional $\mathrm{HO}_{\mathrm{x}} / \mathrm{NO}_{\mathrm{x}}$ chemistry under these conditions. In less polluted regions, model calculations suggest that chemical processes involving $\mathrm{Br}$ and $\mathrm{Cl}$ influence $\mathrm{O}_{3}$ and $\mathrm{NO}_{\mathrm{x}}$ significantly. In the cleanest regime (the ITCZ), simulated $\mathrm{NO}_{\mathrm{x}}$ in the "with halogens" run was a factor of about three lower relative to the "no halogens" run and the corresponding mixing ratios of $\mathrm{OH}$ and $\mathrm{HO}_{2}$ were also substantially lower (Table 4). Taken together, the above results suggest that, in more remote marine regions containing sufficient acidity to titrate sea-salt alkalinity, halogen chemistry significantly modifies the photochemical evolution of the MBL relative to that predicted based on conventional $\mathrm{HO}_{\mathrm{x}} / \mathrm{NO}_{\mathrm{x}}$ photochemistry.

\section{Summary and conclusions}

- The multiphase processing of inorganic $\mathrm{Cl}$ - and $\mathrm{Br}-$ species was characterized over a broad range of physicochemical conditions within four distinct flow regimes along a latitudinal gradient from $51^{\circ} \mathrm{N}$ to $18^{\circ} \mathrm{S}$ through the eastern North and South Atlantic Oceans. Median dry-deposition fluxes of sea salt, total $\mathrm{NO}_{3}$, and total nss $\mathrm{S}$ among the four regimes varied by factors of 25 , 17 , and 9 , respectively.

- Median dry-deposition fluxes of particulate and volatile $\mathrm{Cl}$ and $\mathrm{Br}$ calculated directly from measurements within each regime were approximately balanced by the corresponding production fluxes of $\mathrm{Cl}^{-}$and $\mathrm{Br}^{-}$in association with sea-salt aerosol. These relationships support the hypothesis that the production of sea salt at the ocean surface was the primary source for inorganic $\mathrm{Cl}$ and $\mathrm{Br}$ under all flow regimes.

- Acidification and associated dechlorination of sea-salt aerosol primarily via incorporation of $\mathrm{HNO}_{3}$ sustained
$\mathrm{HCl}$ mixing ratios ranging from median values of 82 to $682 \mathrm{pmol} \mathrm{mol}^{-1}$ (in the ITCZ and EURO regimes, respectively). Corresponding $\mathrm{EF}\left(\mathrm{Cl}^{-}\right) \mathrm{s}$ ranged from 0.86 to 0.94 (in the EURO and N-AFR regimes, respectively).

- Aerosol pHs inferred from the measured phase partitioning of $\mathrm{HCl}$ were similar to modeled values. Median $\mathrm{pHs}$ for most sea-salt size fractions ranged from $\sim 3.0$ in the EURO regime to the $\sim 4.5$ in the ITCZ.

- Simulated daily maximum concentrations of atomic Cl ranged from $2.1 \times 10^{4} \mathrm{~cm}^{-3}$ for the ITCZ to $7.8 \times 10^{4} \mathrm{~cm}^{-3}$ for the N-AFR regime. At these levels, atomic $\mathrm{Cl}$ would have been an important oxidant for alkanes and $\left(\mathrm{CH}_{3}\right)_{2} \mathrm{~S}$ in all regimes. The principal sources for atomic $\mathrm{Cl}$ were $\mathrm{BrCl}$ photolysis and $\mathrm{ClO}+\mathrm{NO} ; \mathrm{BrCl}$ dominated in the three cleaner regimes and $\mathrm{ClO}+\mathrm{NO}$ in the heavily polluted EURO regime. $\mathrm{Cl}_{2}$, produced primarily at night via $\mathrm{HOCl}+\mathrm{Cl}^{-}$, was an important precursor only in the EURO regime. Unlike the situation in a chemically evolving (non-steadystate) pollutant plume over the ocean (e.g., Pechtl and von Glasow, 2007; Lawler et al., 2009), $\mathrm{Cl}_{2}$ recycling via autocatalytic transformations was relatively unimportant. The production and photolysis of $\mathrm{ClNO}_{2}$ was an insignificant source for atomic $\mathrm{Cl}$ under all conditions.

- Simulated HOCl was present in all regimes during the daytime with maximum mixing ratios ranging from 8.8 to $51 \mathrm{pmol} \mathrm{mol}^{-1}$ in the S-ATL and EURO regimes, respectively. However, the solubility of $\mathrm{SO}_{2}$ over the estimated ranges in aerosol-solution $\mathrm{pH}$ range was low and, consequently, oxidation of S(IV) by hypohalous acids was a relatively minor source for $\mathrm{S}(\mathrm{VI})$ in all but the ITCZ regime.

- Relative to sea salt, all individual aerosol samples integrated over particle size were significantly depleted in $\mathrm{Br}^{-}$(median $\mathrm{EF}\left(\mathrm{Br}^{-}\right)=0.25$ ). The highest $\mathrm{EF}\left(\mathrm{Br}^{-}\right) \mathrm{s}$ were in the heavily polluted EURO regime (median $=0.52)$ and the lowest in the relatively cleaner S-ATL regime (median $=0.14$ ). In contrast, simulations based on the autocatalytic halogen activation mechanism as currently understood predict almost complete debromination of the aerosol under all conditions. In addition, simulated $\mathrm{Br}_{t}$ was greater than measured mixing ratios under most conditions. These results point to an important gap in current understanding of chemical processes involving the activation and/or recycling of inorganic $\mathrm{Br}$ in marine air and suggest that the corresponding simulated influences of Br-radical chemistry reported herein represent upper limits.

- In the model, reaction with atomic $\mathrm{Br}$ was a significant chemical sink for $\mathrm{O}_{3}$ in the N-AFR ( $46 \%$ of total), ITCZ 
(35\%), and S-ATL (30\%) regimes but not in the EURO regime $(5 \%)$. Reaction with atomic $\mathrm{Cl}$ accounted for $1 \%$ to $5 \%$ of the total $\mathrm{O}_{3}$ sink in all regimes.

- The simulated formation of halogen nitrates accelerated the oxidation of $\mathrm{NO}_{\mathrm{x}}$ to $\mathrm{HNO}_{3}$ and particulate $\mathrm{NO}_{3}^{-}$ primarily via hydrolysis reactions involving $\mathrm{S}$ aerosol. Lower mixing ratios of $\mathrm{NO}_{\mathrm{x}}$ coupled with direct reactions involving $\mathrm{HO}_{\mathrm{x}}$ and halogens resulted in lower peak simulated $\mathrm{OH}$ concentrations during midday in the Euro (20\%), N-AFR (54\%), ITCZ (29\%), and S-ATL $(40 \%)$ regimes relative to the "no halogens" runs with implications for the lifetimes of reactive trace gases.

- Under all modeled conditions, transformations involving halogens resulted in net $\mathrm{O}_{3}$ destruction. Relative to "no halogens" runs, average steady-state mixing ratios of $\mathrm{O}_{3}$ in the "with halogens" runs were lower by $22 \%$ in EURO, $62 \%$ in N-AFR, $29 \%$ in ITCZ, and $48 \%$ in S-ATL.

- The interrelated influences of halogens on $\mathrm{NO}_{\mathrm{x}}, \mathrm{HO}_{\mathrm{x}}$, and $\mathrm{O}_{3}$ in the model substantially modified oxidation processes and atmospheric lifetimes of reactive trace gases relative to those predicted by conventional $\mathrm{HO}_{\mathrm{x}} / \mathrm{NO}_{\mathrm{x}}$ chemistry. The relative importance of these influences varied as functions of sea-salt concentrations, absolute levels of pollutant-derived species, and the photochemical age of pollutants.

Acknowledgements. We thank Captain Udo Domke and the crew of the Polarstern for outstanding logistical support during the cruise. Lucy Carpenter, Gordon McFiggans, Ulrich Platt and their respective post doctoral fellows, students, and technical staffs collaborated in the field campaign and shared data. Roland von Glasow, Russell Dickerson, Joel Thornton, and three anonymous reviewers offered helpful comments on the manuscript. The Marine and Atmospheric Chemistry Research Laboratory at the University of North Carolina, Wilmington provided facilities for modeling and data interpretation. Financial support was provided by the US National Science Foundation through awards ATM 0328342 and 0646854 to the University of Virginia (UVA) and ATM 0328389 and 0646865 to the University of New Hampshire (UNH) and by NOAA Contract NA03OAR4600122 to UNH. Additional support for the modeling component was provided by the US Department of Energy's Office of Science (BER) (grant number DE-FG02-07ER64442 to UVA and a graduate fellowship through the Global Change Education Program).

Edited by: J. Thornton

\section{References}

Alicke, B., Hebestreit, K., Stutz, J., and Platt, U.: Iodine oxide in the marine boundary layer, Nature, 397, 572-573, 1999.

Bardwell, C. A., Maben, J. R., Hurt, J. A., Keene, W. C., Galloway, J. N., Boatman, J. F., and Wellman, D.: A technique using highflow, dichotomous filter packs for measuring major atmospheric chemical constituents, Global Biogeochem. Cy., 4, 151163, 1990.

Blanchard, D. C., Woodcock, A. H., and Cipriano, R. J.: The vertical distribution of the concentration of sea salt in the marine atmosphere near Hawaii, Tellus, 36B, 118-125, 1984.

Bloss, W. J., Lee, J. D., Johnson, G. P., Sommariva, R., Heard, D. E., Saiz-Lopez, A., Plane, J. M. C., McFiggans, G., Coe, H., Flynn, M., Williams, P., Rickard, A. R., and Fleming Z. L.: Impact of halogen monoxide chemistry upon boundary layer $\mathrm{OH}$ and $\mathrm{HO}_{2}$ concentrations at a coastal site, Geophys. Res. Lett., 32, L06814, doi:10.1029/2004GL022084, 2005.

Carpenter, L. J.: Iodine in the marine boundary layer, Chem Rev., 103, 4953-4962, 2003.

Carsey, T. P., Churchill, D. D., Farmer, M. L., Fischer, C. J., Pszenny, A. A. P., Ross, V. B., Saltzman, E. S., Springer-Young, M., and Bonsang, B.: Nitrogen oxides and ozone production in the North Atlantic marine boundary layer, J. Geophys. Res., 102, 10653-10665, 1997.

Corbett, J. J., Fischbeck, P. S., and Pandis, S. N.: Global nitrogen and sulfur inventories for oceangoing ships, J. Geophys. Res., 104, 3457-3470, 1999.

Dahl, E. E., Yvon-Lewis, S. A., and Saltzman, E. S.: Saturation anomalies of alkyl nitrates in the tropical Pacific Ocean, Geophys. Res. Lett., 32, L20817, doi:10.1029/2005GL023896, 2005.

Dickerson, R. R., Rhoads, K. P., Carsey, T. P., Oltmans, S. J., Burrows, J. P., and Crutzen, P. J.: Ozone in the remote marine boundary layer: A possible role for halogens, J. Geophys. Res., 104, 21385-21395, 1999.

Draxler, R. R. and Rolph, G. D.: HYSPLIT (Hybrid Single-Particle Lagrangian Integrated Trajectory) model access via NOAA ARL READY, NOAA Air Resources Lab., Silver Spring, MD, USA, 2005.

Fickert, S., Adams, J. D., and Crawley, J. N.: Activation of $\mathrm{Br}_{2}$ and $\mathrm{BrCl}$ via uptake of $\mathrm{HOBr}$ onto aqueous salt solutions, J. Geophys. Res., 104, 23719-23727, 1999.

Finley, B. D. and Saltzman, E. S.: Measurement of $\mathrm{Cl}_{2}$ in coastal urban air, Geophys. Res. Lett., 33, L11809, doi:10.1029/2006GL025799, 2006.

Fischer, E., Pszenny, A., Keene, W., Maben, J., Smith, A., Stohl, A., and Talbot, R.: Nitric acid phase partitioning and cycling in the New England coastal atmosphere, J. Geophys. Res., 111, D23S09, doi:10.1029/2006JD007328, 2006.

Foster, K. L., Plastridge, R. A., Bottenheim, J. W., Shepson, P. B., Finlayson-Pitts, B. J., and Spicer, C. W.: The role of $\mathrm{Br}_{2}$ and $\mathrm{BrCl}$ in surface ozone destruction at polar sunrise, Science, 291, 471-474, 2001.

Galbally, I. E., Bentley, S. T., and Meyer C. P.: Mid-latitude marine boundary-layer ozone destruction at visible sunrise observed at Cape Grim, Tasmania, Geophys. Res. Lett., 27, 3841-3844, 2000.

Huebert, B. J., Zhuang, L., Howell. S., Noone, K., and Noone, B.: Sulfate, nitrate, methanesulfonate, chloride, ammonium, and sodium measurements from ship, island, and aircraft during the Atlantic Stratocumulus Transition Experiment/Marine Aerosol Gas Exchange, J. Geophys. Res., 101, 4413-4423, 1996.

Hummelshøj, P., Jensen, N. O., and Larsen, S. E.: Particle dry deposition to a sea surface, in Precipitation Scavenging and Atmosphere-Surface Exchange, edited by: Schwartz, S. E. and 
Slinn, W. G. N., Hemisphere Publ. Corp., Washington, USA, 829-840, 1992

Immler, F. and Schrems, O.: Lidar observations of extremely thin clouds at the tropical tropopause, Reviewed and Revised Papers Presented at the 23rd International Laser Radar Conference, Nara, Japan, 24-28 July 2006, edited by: Nagasawa, C. and Sugimoto, N., 547-550, 2006.

Jacobi, H.-W., Weller, R., Bluszcz, T., and Schrems, O.: Latitudinal distribution of peroxyacetyl nitrate (PAN) over the Atlantic Ocean, J. Geophys. Res., 104(D21), 26901-26912, 1999.

Keene, W. C., Pszenny, A. A. P., Galloway, J. N., and Hawley, M. E.: Sea-salt corrections and interpretation of constituent ratios in marine precipitation, J. Geophys. Res., 91, 6647-6658, 1986.

Keene, W. C., Talbot, R. W., Andreae, M. O., Beecher, K., Berresheim, H., Castro, M., Farmer, J. C., Galloway, J. N., Hoffmann, M. R., Li, S.-M., Maben, J. R., Munger, J. W., Norton, R. B., Pszenny, A. A. P., Puxbaum, H.,Westberg, H., and Winiwarter, W.: An intercomparison of measurement systems for vapor and particulate-phase concentrations of formic and acetic acids, J. Geophys. Res., 94, 6457-6471, 1989.

Keene, W. C., Pszenny, A. A. P., Jacob, D. J., Duce, R. A., Galloway, J. N., SchultzTokos, J. J., Sievering, H., and Boatman, J. F.: The geochemical cycling of reactive chlorine through the marine troposphere, Global Biogeochem. Cy., 4, 407-430, 1990.

Keene, W. C., Maben, J. R., Pszenny, A. A. P., and Galloway, J. N.: Measurement technique for inorganic chlorine gases in the marine boundary layer, Environ. Sci. Technol. 27, 866-874, 1993.

Keene, W. C., Jacob, D. J., and Fan, S.-M.: Reactive chlorine: A potential sink for dimethylsulfide and hydrocarbons in the marine boundary layer, "New Directions" Commentary, Atmos. Environ., 30(6), i-iii, 1996.

Keene, W. C., Sander, R., Pszenny, A. A. P., Vogt, R., Crutzen, P. J., and Galloway, J. N.: Aerosol pH in the marine boundary layer: A review and model evaluation, J. Aerosol Sci., 29, 339-356, 1998.

Keene, W. C., Khalil, M. A. K., Erickson, D. J., McCulloch, A., Graedel, T. E., Lobert , J. M., Aucott, M. L., Gong, S. L., Harper, D. B., Kleiman, G., Midgley, P., Moore, R. M., Seuzaret, C., Sturges, W. T., Benkovitz, C. M., Koropalov, V., Barrie, L. A., and Li, Y. F.: Composite global emissions of reactive chlorine from natural and anthropogenic sources: Reactive Chlorine Emissions Inventory, J. Geophys. Res., 104, 8429-8440, 1999.

Keene, W. C., Pszenny, A. A. P., Maben, J. R., Stevenson, E., and Wall, A.: Closure evaluation of size-resolved aerosol $\mathrm{pH}$ in the New England coastal atmosphere during summer, J. Geophys. Res., 109, D23307, doi:10.1029/2004JD004801, 2004.

Keene, W. C., Stutz, J., Pszenny, A.A. P., Maben, J. R., Fischer, E. V., Smith, A. M., von Glasow, R., Pechtl, S., Sive, B. C., Varner, R. K.: Inorganic chlorine and bromine in coastal New England air during summer, J. Geophys. Res., 112, D10S12, doi:10.1029/2006JD007689, 2007a.

Keene, W. C., Maring, H., Maben, J. R., Kieber, D. J., Pszenny, A. A. P., Dahl, E. E., Izaguirre, M. A., Davis, A. J., Long, M. S., Zhou, X., Smoydzin, L., and Sander, R.: Chemical and physical characteristics of nascent aerosols produced by bursting bubbles at a model air-sea interface, J. Geophys. Res., 112, D21202, doi:10.1029/2007JD008464, 2007b

Lawler, M. J., Finley, B. D., Keene, W. C., Pszenny, A. A. P., Read, K. A., von Glasow, R., and Saltzman, E. S.: Pollutionenhanced reactive chlorine chemistry in the eastern tropical
Atlantic boundary layer, Geophys. Res. Lett., 36, L08810, doi:10.1029/2008GL036666, 2009.

Lee, J. D., Moller, S. J., Read, K. A., Lewis, A. C., Mendes, L., and Carpenter, L.: Year round measurements of nitrogen oxides and ozone in the tropical North Atlantic marine boundary layer, J. Geophys. Res., in press, 2009.

Leser, H., Hönninger, G., and Platt U.: MAX-DOAS measurements of $\mathrm{BrO}$ and $\mathrm{NO}_{2}$ in the marine boundary layer, Geophys. Res. Lett., 30(10), 1537, doi:10.1029/2002GL015811, 2003.

Lewis, E. R. and Schwartz, S. E.: Sea salt aerosol production: Mechanisms, Methods, Measurements, and Models - A Critical Review, in Geophysical Monograph, American Geophysical Union, Washington DC, USA, 152, 413 pp., 2004.

Maben, J. R., Keene, W. C., Pszenny, A. A. P., and Galloway J. N.: Volatile inorganic chlorine in surface air over eastern North America, Geophys. Res. Lett., 22, 3513-3516, 1995.

Maring, H., Savoie, D. L., Izaguirre, M. A., Custals, L., and Reid, J. S.: Vertical distributions of dust and sea-salt aerosols over Puerto Rico during PRIDE measured from a light aircraft, J. Geophys. Res., 108, 8587, doi:10.1029/2002JD002544, 2003

Martino, M., Mills, G. P., Woeltjen, J., and Liss, P. S.: A new source of volatile organoiodine compounds in surface seawater, Geophys. Res. Lett., 36, L01609, doi:10.1029/2008GL036334, 2009.

Matveev, V., Peleg, M., Rosen, D., Tov-Alper, D. S., Hebestreit, K., Stutz, J., Platt, U., Blake, D., and Luria, M.: Bromine oxide - ozone interactions over the Dead Sea, J. Geophys. Res, 106, 10375-10387, 2001.

Nagao, I., Matsumoto, K., and Tanaka, H.: Sunrise ozone destruction found in the sub-tropical marine boundary layer, Geophys. Res. Lett., 26, 3377-3380, 1999.

Neuman, J. A., Parrish, D. D., Trainer, M., Ryerson, T. B., Holloway, J. S., Nowak, J. B., Swanson, A., Flocke, F., Roberts, J. M., Brown, S. S., Stark, H., Sommariva, R., Stohl, A., Peltier, R.,. Weber, R., Wollny, A. G., Sueper, D. T., Hubler, G., and Fehsenfeld, F. C.: Reactive nitrogen transport and photochemistry in urban plumes over the North Atlantic Ocean, J. Geophys. Res., 111, D23S54, doi:10.1029/2005JD007010, 2006.

O’Dowd, C. D., Jimenez, J. L., Bahreini, R., Flagan, R. C., Seinfeld, J. H., Hameri, K., Pirjola, L., Kulmala, M., Jennings, S. G., and Hoffman, T.: Marine aerosol formation from biogenic iodine emissions, Nature, 417, 632-636, 2002.

Osthoff, H. D., Roberts, J. M., Ravishankara, A. R., Williams, E. J., Lerner, B. M., Sommariva, R., Bates, T. M., Coffman, D., Quinn, P. K., Dibb, J. E., Stark, H., Burkholder, J. B., Talukdar, R. K., Meagher, J., Fehsenfeld, F. C., and Brown, S. S.: High levels of nitryl chloride in the polluted subtropical marine boundary layer, Nature Geosci., 1, 324-328, doi:10.1038/ngeo177, 2008.

Pechtl, S. and von Glasow, R.: Reactive chlorine in the marine boundary layer in the outflow of polluted continental air: A model study, Geophys. Res. Lett., 34, L11813, doi:10.1029/2007GL029761, 2007.

Platt, U., Allan, W., and Lowe, D. C.: Hemispheric average $\mathrm{Cl}$ concentrations from ${ }^{13} \mathrm{C} /{ }^{12} \mathrm{C}$ ratios in atmospheric methane, Atmos. Chem. Phys., 4, 1-7, 2004, http://www.atmos-chem-phys.net/4/1/2004/.

Pszenny, A. A. P., Moldanová, J., Keene, W. C., Sander, R., Maben, J. R., Martinez, M., Crutzen, P. J., Perner, D., and Prinn, R. G.: Inorganic halogens and aerosol $\mathrm{pH}$ in the Hawaiian marine boundary layer, Atmos. Chem. Phys., 4, 147-168, 2004, 
http://www.atmos-chem-phys.net/4/147/2004/.

Pszenny, A. A. P., Fischer, E. V., Russo, R. S., Sive, B. C., and Varner, R. K.: Estimates of $\mathrm{Cl}$ atom concentrations and hydrocarbon kinetic reactivity in surface air at Appledore Island, Maine (USA), during International Consortium for Atmospheric Research on Transport and Transformation/Chemistry of Halogens at the Isles of Shoals, J. Geophys. Res., 112, D10S13, doi:10.1029/2006JD007725, 2007.

Read, K. A., Majajan, A. S., Carpenter, L. J., Evans, M. J., Faria, B. V. E., Heard, D. E., Hopkins, J. R., Lee, J. D., Moller, S. J., Lewis, A. C., Mendes, L., McQuaid, J. B., Oetjen, H., SaizLopex, A., Pilling, M. J., and Plane, J. M. C.: Extensive halogenmediated ozone destruction over the tropical Atlantic Ocean, Nature, 453, 1232-1235, 2008.

Roelofs, G.-J., Lelieveld, J., and Ganzeveld, L.: Simulation of global sulfate distribution and the influence on effective cloud drop radii with a coupled photochemistry-sulfur cycle model, Tellus, 50b, 224-242, 1998.

Russell, L. M., Mensah, A. A., Fischer, E. V., Sive, B. C., Varner, R. K., Keene, W. C., Stutz, J., and Pszenny, A. A. P.: Nanoparticle growth following photochemical $\alpha$ - and $\beta$-pinene oxidation at Appledore Island during International Consortium for Research on Transport and Transformation/Chemistry of Halogens at the Isles of Shoals 2004, J. Geophys. Res., 112, D10S21, doi:10.1029/2006JD007736, 2007.

Saiz-Lopez, A. and Plane, J. M. C.: Novel iodine chemistry in the marine boundary layer, Geophys. Res. Lett., 31, L04112, doi:10.1029/2003GL019215, 2004.

Saiz-Lopez, A., Plane, J. M. C., and Shillito, J. A.: Bromine oxide in the mid-latitude marine boundary layer, Geophys. Res. Lett., 31, L03111, doi:10.1029/2004GL018956, 2004.

Sander, R., Rudich, Y., von Glasow, R., and Crutzen, P. J.: The role of $\mathrm{BrNO}_{3}$ in marine tropospheric chemistry: a model study. Geophys. Res. Lett., 26, 2857-2860, 1999.

Sander, R., Keene, W. C., Pszenny, A. A. P., Arimoto, R., Ayers, G. P., Baboukas, E., Cainey, J. M., Crutzen, P. J., Duce, R. A., Hönninger, G., Huebert, B. J., Maenhaut, W., Mihalopoulos, N., Turekian, V. C., and Van Dingenen, R.: Inorganic bromine in the marine boundary layer: a critical review, Atmos. Chem. Phys., 3, 1301-1336, 2003, http://www.atmos-chem-phys.net/3/1301/2003/.

Sander, R., Kerkweg, A., Jöckel, P., and Lelieveld, J.: Technical Note: The new comprehensive atmospheric chemistry module MECCA, Atmos. Chem. Phys., 5, 445-450, 2005, http://www.atmos-chem-phys.net/5/445/2005/.

Sander, R., Gromov, S., Harder, H., Jöckel, P. Kerkweg, A., Kubistin, D., Riede, H., Taraborrelli, D., and Tost, H.: The atmospheric chemistry box model CAABA/MECCA-3.0, Geosci. Model Dev., in preparation, 2009.

Sandu, A. and Sander, R.: Technical Note: Simulating chemical systems in Fortran90 and Matlab with the kinetic preprocessor KPP-2.1, Atmos. Chem. Phys., 6, 187-195, 2006, http://www.atmos-chem-phys.net/6/187/2006/.

Shepon, A., Gildor, H., Labrador, L. J., Butler, T., Ganzeveld, L. N., and Lawrence, M. G.: Global reactive nitrogen deposition from lightning $\mathrm{NO}_{\mathrm{x}}$, J. Geophys. Res., 112, D06304, doi:10.1029/2006JD007458, 2007.

Simpson, W. R., von Glasow, R., Riedel, K., Anderson, P., Ariya, P., Bottenheim, J., Burrows, J., Carpenter, L. J., Frieß, U., Goodsite,
M. E., Heard, D., Hutterli, M., Jacobi, H.-W., Kaleschke, L., Neff, B., Plane, J., Platt, U., Richter, A., Roscoe, H., Sander, R., Shepson, P., Sodeau, J., Steffen, A., Wagner, T., and Wolff, E.: Halogens and their role in polar boundary-layer ozone depletion, Atmos. Chem. Phys., 7, 4375-4418, 2007.

Stohl, A., Forster, C., Frank, A., Seibert, P., and Wotawa, G.: Technical note: The Lagrangian particle dispersion model FLEXPART version 6.2., Atmos. Chem. Phys., 5, 2461-2474, 2005, http://www.atmos-chem-phys.net/5/2461/2005/.

Stickel, R. E., Nicovich, J. M., Wang, S., Zhou, Z., and Wine, P. H.: Kinetic and mechanistic study of the reaction of atomic chlorine with dimethyl sulfide, J. Phys. Chem., 96, 9875-9883, 1992.

Stutz, J., Hebestreit, K., Alicke, B., and Platt, U.: Chemistry of halogen oxides in the troposphere: Comparison of model calculations with recent field data, J. Atmos. Chem., 34, 65-85, 1999.

Tanaka, P. L., Riemer, D. D., Chang, S., Yarwood, G., McDonaldBuller, E. C., Apel, E. C., Orlando, J. J., Silva, P. J., Jimemez, J. L., Canagaratna, M. R., Neece, J. D., Mullins, C. B., and Allen, D. T.: Direct evidence for chlorine-enhanced urban ozone formation in Houston, Texas, Atmos. Environ., 37, 1393-1400, 2003.

Thompson, A. M. and Zafiriou, O. C.: Air-sea fluxes of transient atmospheric species, J. Geophys, Res., 88, 6696-6708, 1983.

Toumi, R.: BrO as a sink for dimethylsulfide in the marine atmosphere, Geophys. Res., Lett., 21, 117-120, 1994.

Valigura, R. A.: Iterative bulk exchange model for estimating airwater transfer of $\mathrm{HNO}_{3}$, J. Geophys. Res., 100(D12), 2604526050, 1995

Vogt, R., Crutzen, P. J., and Sander, R.: A mechanism for halogen release from sea-salt aerosol in the remote marine boundary layer, Nature, 383, 327-330, 1996.

Von Glasow R, Sander, R., Bott, A., and Crutzen, P. J.: Modeling halogen chemistry in the marine boundary layer . 1. Cloud-free MBL, J. Geophys. Res., 107, 4341, doi:10.1029/2001JD000942, 2002a.

Von Glasow, R., Sander, R., Bott, A., and Crutzen, P. J.; Modeling halogen chemistry in the marine boundary layer. 2. Interactions with sulfur and cloud-covered MBL, J. Geophys. Res., 107, 4323, doi:10.1029/2001JD000943, 2002b.

Wennberg, P. O., Cohen, R. C., Stimpfle, R. M., Koplow, J. P., Anderson, J. G., Salawitch, R. J., Fahey, D. W., Woodbridge, E. L., Keim, E. R., Gao, R. S., Webster, C. R., May, R. D., Toohey, D. W., Avallone, L. M., Proffitt, M. H., Loewenstein, M., Podolske, J. R., Chan, K. R., and Wofsy, S. C.: Removal of stratospheric $\mathrm{O}_{3}$ by radicals: In situ measurements of $\mathrm{OH}, \mathrm{HO}_{2}, \mathrm{NO}, \mathrm{NO}_{2}$, ClO, and BrO, Science, 266, 398-404, 1994.

Willeke, K.: Performance of the slotted impactor, Amer. Indus. Hygiene Assoc. Journal, 36, 683-691, 1975.

Williams, P. I., McFiggans, G., and Gallager, M. W.: Latitudinal aerosol size distribution variation in the Eastern Atlantic Ocean measured aboard the FS-Polarstern, Atmos. Chem. Phys., 7, 2563-2573, 2007, http://www.atmos-chem-phys.net/7/2563/2007/.

Wingenter, O. W., Kubo, M. K., Blake, N. J., Smith Jr., T. W., Blake, D. R., and Rowland, F. S.: Hydrocarbon and halocarbon measurements as photochemical and dynamical indicators of atmospheric hydroxyl, atomic chlorine and vertical mixing obtained during Lagrangian flights, J. Geophys. Res., 101, 4331-4340, 1996. 